
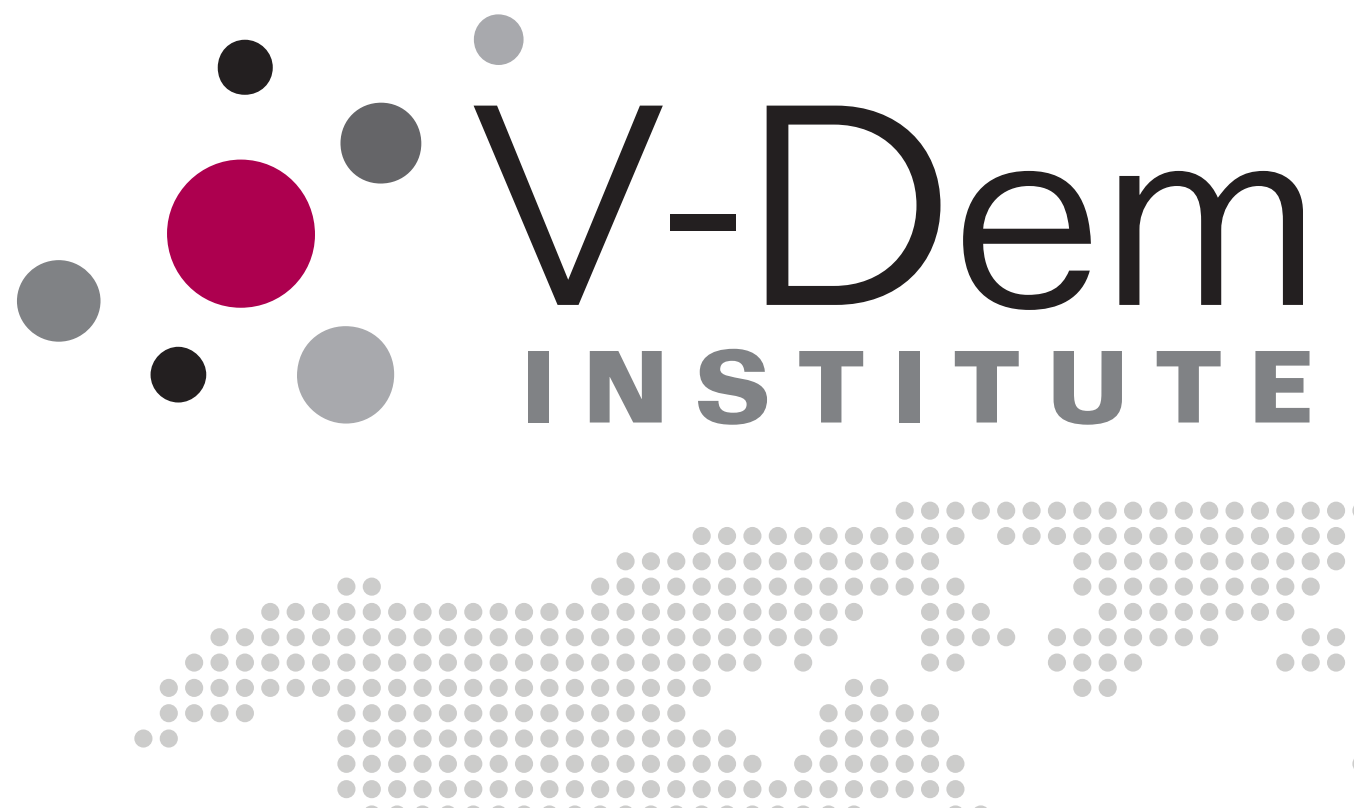

\title{
Visualizing Authority Patterns over Space and Time
}

Vanessa A. Boese, Scott Gates, Carl Henrik Knutsen, Håvard Mokleiv Nygård, Håvard Strand

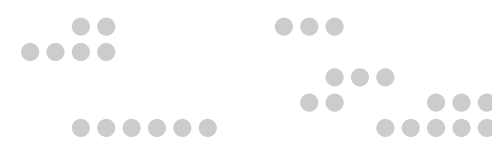

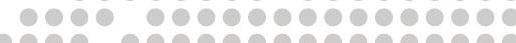

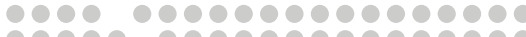

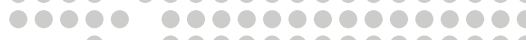
-

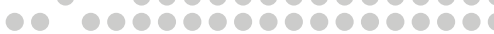
o.

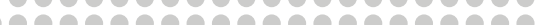

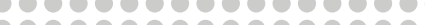

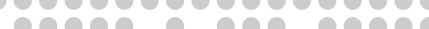
reroror 60

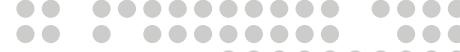

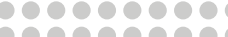
bos

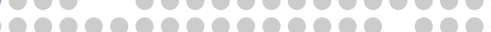

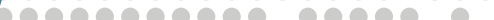

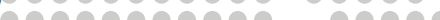

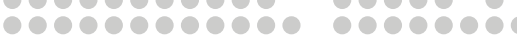
100000800000 1000000000000000000

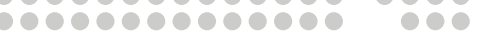
600000000090000

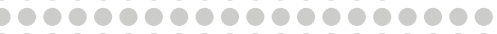
P00000000000000000 10000080000000000

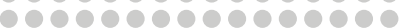

10000000000000

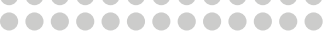

0000000000

00000000000

0

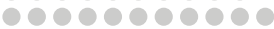

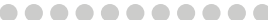

90900000000

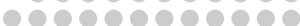

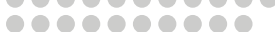
6е890808

00000000 1000000

1000000

000000

00000000

0000000

1000

9000000

00

100080

0000

000

100

10

10

90

P

February 2020

Working Paper

SERIES 2020:96

THE VARIETIES OF DEMOCRACY INSTITUTE

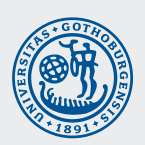

UNIVERSITY OF GOTHENBURG

DEPT OF POLITICAL SCIENCE 
Varieties of Democracy (V-Dem) is a new approach to conceptualization and measurement of democracy. The headquarters - the V-Dem Institute - is based at the University of Gothenburg with 20 staff. The project includes a worldwide team with six Principal Investigators, 14 Project Managers, 30 Regional Managers, 170 Country Coordinators, Research Assistants, and 3,000 Country Experts. The V-Dem project is one of the largest ever social science research-oriented data collection programs.

Please address comments and/or queries for information to:

V-Dem Institute

Department of Political Science

University of Gothenburg

Sprängkullsgatan 19, PO Box 711

SE 40530 Gothenburg

Sweden

E-mail: contact@v-dem.net

V-Dem Working Papers are available in electronic format at www.v-dem.net.

Copyright (C2020 by authors. All rights reserved. 


\title{
Visualizing Authority Patterns
}

\section{over Space and Time*}

\author{
Vanessa A. Boese ${ }^{1}$, Scott Gates ${ }^{2,3}$, Carl Henrik Knutsen ${ }^{2}$, \\ Håvard Mokleiv Nygård ${ }^{3}$, and Håvard Strand ${ }^{2,3}$ \\ ${ }^{1}$ V-Dem Institute, University of Gothenburg \\ ${ }^{2}$ University of Oslo, Norway \\ ${ }^{3}$ Peace Research Institute Oslo (PRIO), Norway
}

*The authors would like to thank Staffan I. Lindberg, Johannes von Römer, Sebastian Schütte as well as the participants at the 2019 PEDD conference, the EPSA 2019 conference, the 2019 ISA conference, the V-Dem visiting scholar seminar 2019 at the University of Gothenburg, and the Jan Tinbergen NEPS conference 2018 for excellent comments and suggestions. The Research Council of Norway, grant nr. 275400, provided funding for this paper. 


\section{Abstract}

Unidimensional measures of democracy fail to account for the complex and varied nature of political systems. This article disaggregates the concept of democracy and proposes a multidimensional conceptualization to account for this variation in institutional configurations. Three theoretically informed dimensions are featured: participation, electoral contestation, and constraints on the executive. The three dimensions constitute a cube covering all regime types, in which we place countries using V-Dem data from 1789 to 2018. The cube of democracy patterns reveals several interesting observations. We trace historical patterns of democratization and autocratization, and discuss how global and regional developments take different paths at different times. Our conceptualization makes it clear that political systems with a similar score along a unidimensional scale can in fact be quite distinct. In addition, across the globe over 200 years, certain configurations of political institutions never occur. In other words, incompatible institutional pairs do not exist or are extremely short lived. This multidimensional conceptualization ultimately opens up a new field of research in which institutional change can be studied in greater detail across countries and over time.

Keywords: Measuring democracy, institutions, Varieties of Democracy (V-Dem) Data, institutional incompatibility 


\section{Introduction}

Despite all the attention placed on tracing and properly describing the evolution of democracy throughout modern history, debate persists as to when, how and by how much democracy has developed in different regions of the world. Much of this debate has featured general conditions of democracy but has failed to address the multifaceted and complex nature of regimes. The variegated institutional constellations and the multiple dimensions of patterns of authority have received inadequate attention..$^{1}$

Two obstacles have stood in the way of examining the evolution of democratic institutions over time, especially from the origins of modern democracy in the late 1700s. First, until recently, there has been a lack of fine-grained indicators of several aspects of democracy before 1900. The lack of valid measures that are comparable across countries and extensive periods of time make accurate descriptions of trends in democracy very difficult.

Second, even for more recent decades - for which there is good data coverage on measures that capture different aspects of democracy - it is inherently hard to give a description of regime developments that is nuanced and easy-to-grasp at the same time. Researchers often construct and evaluate composite democracy indices - even when they operate with multiple relevant dimensions of democracy - that aggregate up the different features into one single score. The problem with this approach, as Cheibub, Gandhi, and Vreeland (2010) note, is that a large number of different combinations of scores on each dimension could give the same aggregated index score. For example, a democracy index combining the freeness and fairness of elections with extensiveness of suffrage could show similar scores for the "competitive oligarchy" (Dahl, 1971) in early 19th century Britain (relatively free and fair elections, but relatively low levels of suffrage) and the "electoral authoritarian regime" (Schedler, 2002) of contemporary Russia (high on suffrage, not very free and unfair elections).

The common approach of describing regime differences as well as regime developments over time with changes in aggregated "democracy scores" masks considerable relevant variation. An alternative to this approach could be to focus either on more restricted democracy measures, e.g. mainly capturing the competitiveness of elections (Cheibub, Gandhi, and Vreeland, 2010), focus on certain democracy-relevant indicators such as suffrage (Przeworski, 2009), or on the evolution of certain sub-types of regimes, such as "competitive authoritarian regimes" (Levitsky

\footnotetext{
${ }^{1}$ Throughout the paper, we refer to patterns of authority, democracy, regime types, institutional configurations interchangeably.
} 
and Way, 2010). However, if one wants to make a comprehensive description of regime developments, each of these alternative options has the drawback of leaving much relevant information on the table.

In this paper we resolve the first issue on the dearth of data for early modern history by employing the V-Dem dataset (Coppedge et al., 2019a), which includes the newly released Historical V-Dem data. This resource allows us to leverage a large number of specific indicators on different aspects of democracy for countries across the world, with time series extending from 1789 to the present.

We resolve the second issue by taking a disaggregated, multi-dimensional approach to measuring democracy. More specifically, we draw on, and further refine, the approach to conceptualizing and describing political regimes developed in Gates et al. (2006). Invoking the three core dimensions of contested elections to public offices, constraints on executive decisionmaking authority, and extent of political participation - which make up the core features of most common understandings of "liberal democracy" (see, e.g. Dahl (1971), Coppedge et al. (2011), Gates et al. (2006)) describe and portray political regimes as being located in a threedimensional space. Different parts of this "cube" can thus represent quite distinct political regimes. Often, such regimes are located quite far from each other in the three-dimensional space (e.g., early 19th century Britain and contemporary Russia) yet receive similar scores on aggregated democracy indices such as Polity2, Freedom House or V-Dem's Liberal Democracy Index. Disaggregating the latent concept of democracy into theoretically informed dimensions allows for a more detailed observation of (and ultimately inference on) global developments of authority patterns. This paper therefore demonstrates the benefits of multidimensional democracy measurement by way of example for two different models: the narrow participation model (in which participation is measured as suffrag $2^{2}$ ) and the broad participation model (in which the participation dimension includes suffrage as well as elements inhibiting the voter's ability to fully participate in the electoral process). Each of the models provides different insights along different dimensions.

In sum, by using the rich, disaggregated data from V-Dem and by further developing the multi-dimensional approach by Gates et al. (2006), we provide a comprehensive and nuanced description of regime developments across the world throughout the course of modern history. As the qualitative literature on democratization patterns has long highlighted, we illustrate

\footnotetext{
${ }^{2}$ Empirically, this is conceptually close to participation as used by Dahl $(1971)$.
} 
that these global developments mask substantial variations across regions. We also go beyond describing "typical" regimes to providing systematic measures of the dispersion of regimes in our multi-dimensional space, and how this has evolved over time. We construct a number of indices that capture the distribution of regimes, leveraging these indices to discuss the extent to which institutional heterogeneity has increased or decreased during different parts of modern history. Finally, we pay attention to those parts of our multi-dimensional space that have been left unoccupied either during large parts- or throughout the time period under study. In other words, we describe and discuss logically possible combinations of regime institutions that have not (or very rarely) been observed since 1789. We rely on different manners of visual presentation to highlight different empirical patterns. We present the data in a threedimensional cube or in a two-dimensional figure with the three components disaggregated.

In addition to tracing global patterns of political institutions over time this paper makes a conceptual contribution which may help advance future empirical work studying the causes or effects of political regimes and institutions. The interactions of democracy with socio-economic, security or environmental outcomes have been extensively empirically examined. These studies provide answers to questions such as "why don't democracies fight one another?" (Dafoe, Oneal, and Russett, 2013 Henderson, 1998), "does democracy reduce environmental degradation?" (Li and Reuveny, 2006), "does foreign aid promote democracy?" (Knack, 2004), or "does democracy cause economic growth?" (Acemoglu et al., 2019). Nevertheless, they constitute but a first step in understanding the true mechanism through which institutional configurations affect real world outcomes. Multidimensional approaches to democracy measurement, such as the one put forward in this paper, allow for an identification of the precise aspects of political regimes that interact with a given outcome. Hence, in addition to offering new insights on democracy development worldwide, multidimensional democracy measurement will advance the research frontier by providing the basis for a substantially more detailed identification of the interactions between democracy and economic, security or environmental outcomes.

The paper proceeds as follows: first, we provide a conceptual discussion of our multidimensional regime concept, focusing on the two models proposed (narrow and broad participation model). Second, we go through the different V-Dem indicators used to appropriately measure attributes of the different dimensions, and discuss how we aggregate them. Third, we illustrate our approach to visualizing and describing regimes and regime developments over time, drawing on selected country histories. Fourth, we describe developments in the institu- 
tional make-up of typical- and most democratic regimes, first globally and then by geographical region. Fifth, we measure and describe the dispersion of regimes and institutional heterogeneity at different points in time. Before concluding, we discuss institutional constellations that form regime types that are logically possible but have been empirically rare or non-existent.

\section{Dimension selection}

Democracy is a contested concept and a number of definitions exist, for example with some authors conceptualizing democracy as a set of institutions and others as the fulfillment of some underlying principles ${ }^{3}$ Different definitions of democracy are suitable for different research questions as they provide different insights. Nevertheless, the point of this paper is to emphasize the multidimensional nature of the concept.

In the conceptual literature, there is a long tradition for thinking about democracy in multiple dimensions. Dahl (1971), for example, proposed that regimes could be arranged along two dimensions, with regimes differing both in terms of contestation and participation. The first refers to the extent of real competition in selection of political elites to public offices, whereas the second refers to the extent to which participation rights in determining this contest is widely distributed. While being considered a democracy requires high scores on both dimensions, countries might score high on one of these dimensions and low on the other. For instance, the Soviet Union would score high on participation but low on contestation, and Apartheid South Africa would score high on contestation but low on participation. Thus, while neither is a democracy, these are clearly different types of regimes. Disaggregating into different dimensions thus has benefits in terms of allowing for more refined categorizations and accurate description of regimes. Further, Dahl, for instance, hypothesized that the sequence in which countries developed on the different dimensions may even have implications for regime stability and substantive policy outcomes - one hypothesis is that enhanced stability and better policy outcomes follow from developing on the contestation dimension prior to the participation dimension (see also Huntington, 1968). Hence, operating with multi-dimensional regime concepts could allow us to better understand salient causal relationships.

While extant democracy indices often draw on several sub-indices, currently the norm is, in the end, to use unidimensional measures of democracy, such as the Electoral Democracy

\footnotetext{
${ }^{3}$ For detailed discussions of the notion of democracy as a latent variable, for example, see Goertz $(2006)$ or Treier and Jackman (2008).
} 
Index from V-Dem or Polity2 by the PolityIV Project, in statistical analyses of the determinants or effects of political regimes. This paper, however, argues for a fundamental change in the way we conceptualize democracy in empirical research: rather than thinking about democracy as a single number on a unidimensional scale, it should be conceptualized as a configuration of several dimensions 4

How should these dimensions be defined? To obtain useful and interpretable insights defining the dimensions in a manner consistent with theory is key. That way we can move beyond data mining and advance political theory. As examples, this paper presents multidimensional results for two separate three-dimensional specifications of democracy, a narrow and a broad participation model. We highlight the different insights gained through each specification, in different illustrations, and show benefits relative to unidimensional measures. In the following section, the theory underlying the multi-dimensional conceptualizations is discussed, followed by a more technical overview of how each dimension is constructed empirically.

\subsection{Deriving theory-based dimensions}

While the definition of "democracy" constitutes a hotly debated field of research.5 there is a consensus on its core, contained even in minimal definitions of the concept, namely contested elections $6^{6}$ There are several ways to distribute power within a society. However, only elections are democratic. That does not mean that all elections are democratic. The usual reasons that elections fail to be democratic are lack of contestation and participation. In their pure form, participation is the right to vote and contestation is the right to be voted on, but as we will see, these terms are somewhat intertwined.

The third element, which moves us beyond a minimalist definition of democracy, are constraints placed on the executive between elections. Eckstein (1973) and Gurr (1974), for example, theorized that key dimensions of democracy are the regulation of executive recruitment (contestation), the extent of the franchise (i.e. suffrage/participation), and the limitation of

\footnotetext{
${ }^{4}$ There are substantial differences in concepts coded by different unidimensional indices of democracy (see e.g. Boese (2019)). Hence, we compare and contrast our three-dimensional conceptualizations to unidimensional V-Dem indices that are constructed from similar low-level indicators as our cubes of democracy patterns. In doing so we minimize the chances that differences in variation between uni- and multidimensionl measures are driven by content coded.

${ }^{5}$ For an overview of discussions of the concept "democracy" see for example Munck (2016).

${ }^{6}$ See, for example, Schumpeter $\left.1976[1942]\right)$ or Dahl (1971).
} 
power itself. The latter is mainly found in the institutions that provide checks and balances between the branches of government (especially executive constraints) 7

Apart from purely defining the concept of "democracy" several scholars have related these three democracy dimensions to democratic stability. Dahl (1971), for example, argued that the order in which the dimensions contestation and participation develop matters for democratic stability. Eckstein (1973) postulated a theory of congruence and consonance, whereby "political institutions perform better if their authority patterns are congruent with those of social institutions and, importantly, if they are internally consonant" (Knutsen and Nygård, 2015: 657). Gates et al. (2006) also feature these three dimensions with different parameterization and some different measures. They argue that democracies constitute a re-enforcing equilibrium: Democratic institutions, (1) fair elections (i.e. contestation), (2) institutionalized and widespread participation, and (3) limited executive authority (i.e. executive constraints), reinforce one another. As Przeworski (1991) states: "Democracy will evoke generalized compliance, it will be self-enforcing, when all the relevant political forces have some specific minimum probability of doing well under the particular system of institutions" (pp. 30 - 31). Political elites thereby find they have more to gain in the long run by preserving the power-diffusing democratic institutions than by subverting or undermining them. Constitutional restrictions in democracies further raise the costs of subverting democratic institutions to ensure that the "stakes of political battles" are kept low (Przeworski, 1991; 36). Diamond summarizes this point nicely: "Elites choose democracy instrumentally because they perceive that the costs of attempting to suppress their political opponents exceed the costs of tolerating them (and engaging them in constitutionally regulated competition)" (Diamond, 1994: 3).

Together, these three dimensions describe a number of potential equilibria. The democratic equilibrium is described above. Competing elites will limit executive power and open the electoral process to voters and candidates alike, thereby vesting everyone in the system. Any popular opposition movement can win within the system at a lower cost than challenging the system itself. The autocratic equilibrium is the black hole of political power. All power is vested in a single person, and person, party or office has the potential to challenge this person. Between these, there are several other potential equilibria. The oligarchy is a system where two or more competing elites join forces to block a significant part of society from

\footnotetext{
${ }^{7}$ Gurr (1974) also includes directiveness of the social unit/governmental regulation and complexity of decision structures or governmental decentralization, but these dimensions are not further pursued as the Polity project developed.
} 
power. These competing elites have a common interest in maintaining the blockade and will therefore rather lose an election to the competitor than bring down the system. Elections are competitive among the few that are allowed to vote, power is limited within the system but a large section of the population is barred from voting and competing for office. Apartheid South Africa is the best example of this kind of system, and it remained stable as long as the white minority was cohesive. Most 1800-century Western democracies would block women and people of low income from political participation. This equilibrium was untenable due to two concurrent challenges. One party (the more liberal) believed that expanding the right to vote would give them more voters and the risk of outside political action from excluded elites in organized labour was a real threat to the system as a whole. Another equlibrium is an electoral autocracy with no limitations on the executive power and strict limitations on elections. A key problem in autocracies is that a dictator cannot trust anyone Malesky (2011). Elections can be used to gain some credible information about the preferences of the populations. However, this is risky, Knutsen, Nygård, and Wig (2017). The same election can empower opposition forces and will offer an opportunity to overcome collective action problems, as seen in the many color revolutions over the last decade. A similar equilibrium is the kleptocracy, often found in poor but resource-rich countries. These systems are based on economies largely built around the income from export of natural resources. The democratic equilibrium is based on executive constraints limiting political authority and keeping the stakes of political contests low. When government income largely is based on tax income from voters, this model is feasible. In kleptocratic systems, the income from natural resources are overwhelming, which makes the stakes very high. A potential equilibrium in systems like this are contested elections with no effective limits on the executive power. Whomever is in power is free to distribute political favours to their supporters, and to stash away as much as possible in a Swiss bank in anticipation of a relatively short reign.

As outlined above, these three dimensions, constraints on the executive, contestation and participation describe a range of possible equilibria that have been subject to much theoretical discourse. Our conceptualization does not seek to establish a new universally accepted definition of democracy or regime constellations. Rather, the aim of this paper is to reveal the benefits of empirically accounting for variegated institutional configurations. Our multi-dimensional visualization of the three theory consistent dimensions over time serves as an example and 
allows for more detailed empirical inference and observation of the development of each of these particular dimensions than ever before ${ }^{8}$

\subsection{Quantifying the dimensions}

Similar to the notion of "democracy" each dimension (contestation, participation and constraints on the executive) captures a latent concept. In quantifying these concepts, decisions must be made that affect the final coding of the dimension. Take participation as an example: widespread and institutionalized participation is a critical dimension of democracy. The ability for the people to be able to "vote the bums out" is critical and serves as a safeguard against a leader attempting to accrue too much power. Citizen consensus in support of constitutional restrictions plays an important role in raising the cost of subverting democratic institutions. As pointed out by Weingast (1997), "[r] estrictions on governing elites can only be binding if there exists a citizen consensus to react against tomorrow's incumbents if they attempt to rig elections" (p. 255). Voters play a critical role in democracy. Hence, a possible solution is to measure participation using the share of population with suffrage as denoted in the constitution.

Figure 1 displays regional average shares of population with suffrage across world regions. While suffrage was a crucial dimension to democracy in the past 230 years, in the more recent past (since around 1950 and especially after 2000) there is very little if any variation in suffrage levels for most of the world regions. For these time periods the share of people allowed to vote by law does no longer provide useful information distinguishing between different types of institutional arrangements. The importance of the suffrage dimension, in this regard, has changed over time.

What is more, one may interject against a narrow understanding of the concept of participation that a necessary component of a functioning democracy remains that people must have the means and the opportunity for actual participation in the political decision finding process. How can this participation component be measured in a way to better reflect today's realities? In the vast majority of countries today suffrage is universal. In several countries voting irregularities, however, such as vote buying, ballot stuffing or flawed voter registries, are common. Figure 2 displays regional averages of V-Dem's voting irregularities measure (v2elirreg) $\sqrt[9]{ }$ across

\footnotetext{
${ }^{8}$ Naturally, adding more dimension would theoretically be possible but in practise hard to visualize.

${ }^{9}$ The voting irregularities measure v2elirreg answers the question "In this national election, was there evidence of other intentional irregularities by incumbent and/or opposition parties, and/or vote fraud? Clarification: Examples include use of double IDs, intentional lack of voting materials, ballot stuffing, misreporting of votes, and false collation of votes", (Coppedge et al., 2019b 57). The measure in Figure 2 is rescaled $\in[0,1]$, with
} 


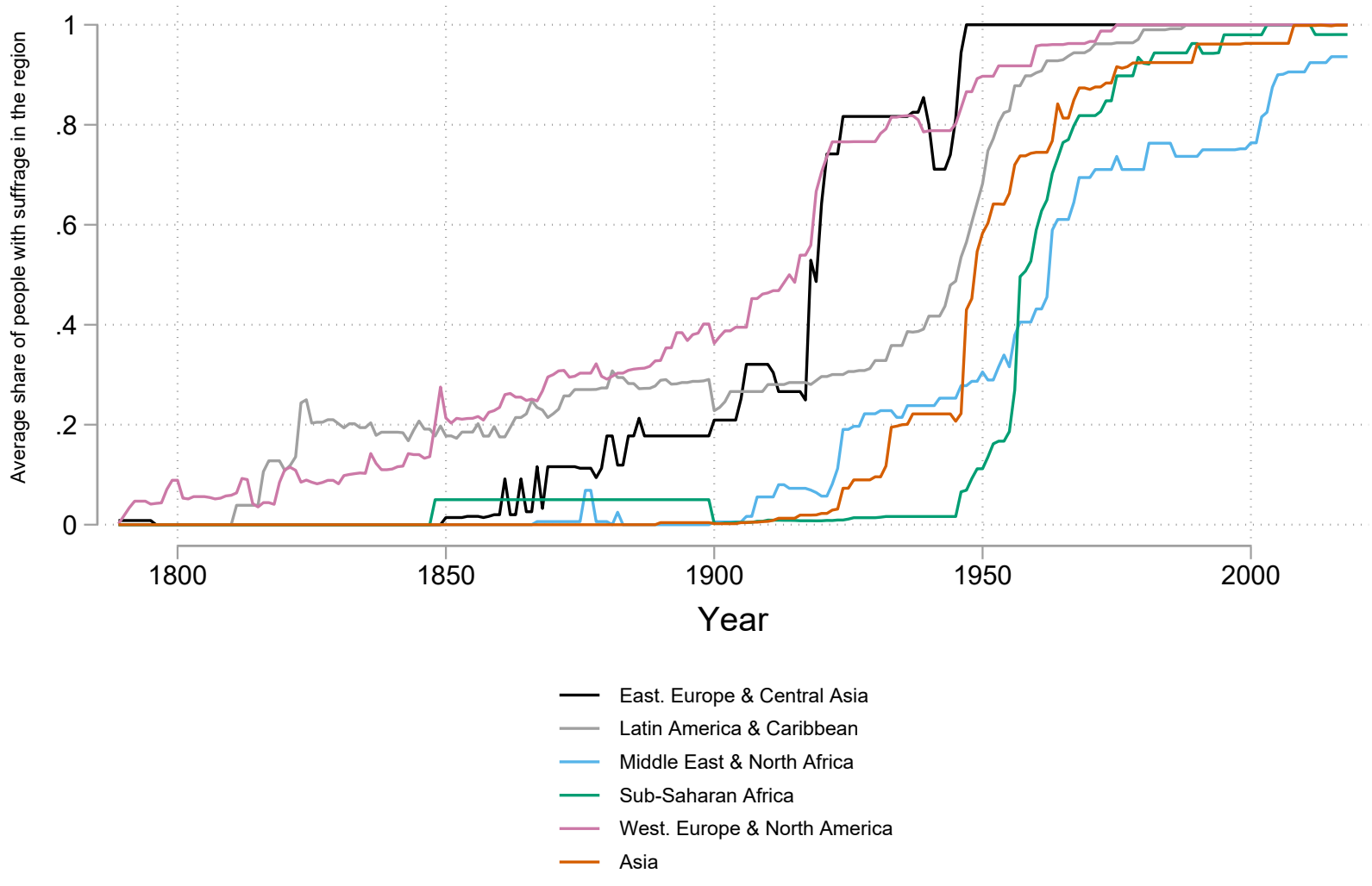

Figure 1: Average share of population with suffrage across world regions, 1789-2018

world regions. It paints a different picture than Figure 1; it shows that even though voters today have the right to cast their votes in the mast majority of countries, voting irregularities are hindering them to fully and meaningfully participate in several countries.

For that reason, this paper provides two alternative approaches to three-dimensional democracy measurement: a narrow participation model and a broad participation model. Table 1 presents an overview of each model's dimensions 10 The narrow participation model follows the "classic" definition of participation as the share of people with suffrage. The broad participation includes measures of voting irregularities in addition to suffrage to capture the actual extent to which people can participate in the political process by casting their votes. The following section discusses each dimension and its components for both models in more detail.

values close to 0 being equivalent to widespread heavy irregularities and values close to 1 reflecting the absence of such.

${ }^{10}$ Table 7 of the Appendix provides an overview of the indicators used to quantify each dimension. 


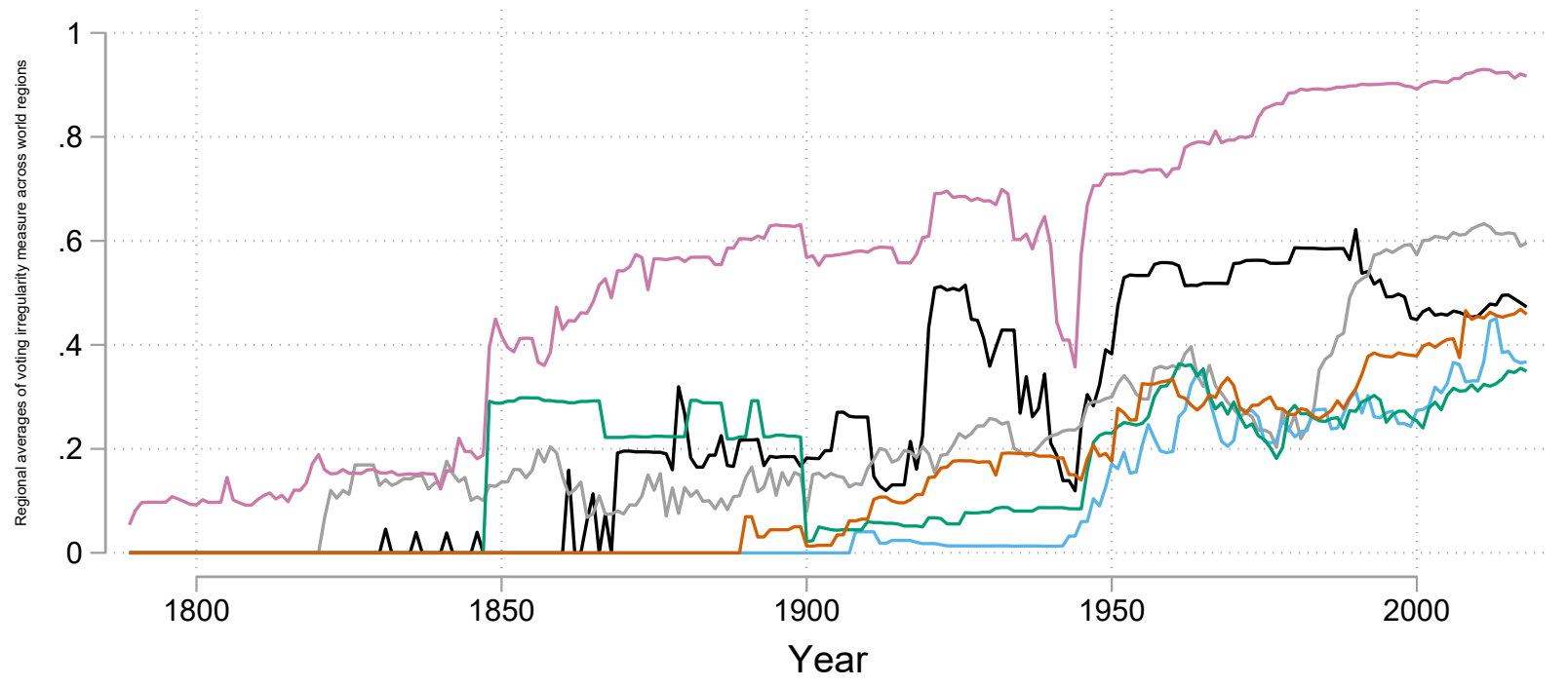

- East. Europe \& Central Asia

- Latin America \& Caribbean

- Middle East \& North Africa

- Sub-Saharan Africa

- West. Europe \& North America

- Asia

Figure 2: Regional averages of V-Dem's voting irregularities measure (v2elirreg) across world regions, 1789-2018.

\subsubsection{Constraints on the executive}

The executive constraints dimension consists of two indices capturing judicial as well as legislative checks and limitations to the executive. The first index, v2x_jucon, provides an answer to the following question: To what extent does the executive respect the constitution and comply with court rulings, and to what extent is the judiciary able to act in an independent fashion?, (Coppedge et al., 2019b: 46). The legislative constraints on the executive are accounted for by the index, v2xlg_legcon, providing information on the extent to which the legislature and government agencies, e.g., comptroller general, general prosecutor, or ombudsman, (are) capable of questioning, investigating, and exercising oversight over the executive, (Coppedge et al., 2019b: 46).

\subsubsection{Contestation}

The manner in which the executive is recruited is a fundamental part of the contestation dimension. When power is transferred in the political system are the subsequent superordinates 
NARRow PARTiCIPATION MODEL

\begin{tabular}{lll} 
constraints on the executive & participation & contestation \\
\hline - judicial constraints & - share of population with & - EMB* autonomy \\
- legislative constraints & suffrage & - EMB capacity \\
& - election government intimidation \\
& - elected officials index \\
& - election voter registry \\
& - election vote buying \\
& - election other voting irregularities \\
\hline \hline
\end{tabular}

Broad Participation Model:

\begin{tabular}{lll} 
constraints on the executive & participation & contestation \\
\hline - judicial constraints & - share of population with & - EMB autonomy \\
- legislative constraints & suffrage & - EMB capacity \\
& - election voter registry & - election government intimidation \\
& - election vote buying & - elected officials index \\
& - election other voting & \\
& irregularities & \\
\hline
\end{tabular}

${ }^{*} \mathrm{EMB}=$ election management body

Table 1: Two conceptualizations of contestation, participation and constraints: narrow and broad participation model

chosen by appointment or by an electoral system? The V-Dem index providing an answer to this question is the elected officials index, v2x_elecoff 111 It represents the de jure aspect of the contestation dimension.

Elections in themselves, however, are not necessarily competitive. Therefore, additional indices capturing the competitiveness and the fairness of the elections are included. An election, in general, can be fair on two sides: the voter as well as the candidate side. The candidate side refers to the competition between the candidates before votes are cast by the voters. Three V-Dem indices are included to capture this candidate contestation: Election Management Body (EMB) autonomy (v2elembaut) ${ }^{12}$ EMB capacity (v2elembcap) ${ }^{13}$ and election government

${ }^{11}$ Is the chief executive and legislature appointed through popular elections? (...) This index attempts to measure (a) whether the chief executive is elected, either directly elected through popular elections or indirectly through a popularly elected legislature that then appoints the chief executive; and (b) whether the legislature, in presidential systems with a directly elected president that is also chief executive, is directly or indirectly elected. Note that a popular election is minimally defined and also includes sham elections with limited suffrage and no competition. Similarly, "appointment" by legislature only implies selection and/or approval, not the power to dismiss., (Coppedge et al., 2019b: 44).

${ }^{12}$ Does the Election Management Body (EMB) have autonomy from government to apply election laws and administrative rules impartially in national elections? (...) The EMB refers to whatever body (or bodies) is charged with administering national elections, (Coppedge et al., 2019b: 54).

${ }^{13}$ Does the Election Management Body (EMB) have sufficient staff and resources to administer a well-run national election? (Coppedge et al., 2019b: 55). 
intimidation (v2elintim) $4^{14}$ Irregularities affecting the fairness of the election on the voters side, for example vote buying or voter intimidation, inherently curtail the voters sphere of influence and their opportunity to participate in the political process. Hence, they are included in the participation dimension of the broad participation model.

It is worth noting that the mode of power transfer in a system (in democracies: elections) and the quality of that mode (are these elections fraudulent or "clean?) form a complementary relationship when assessing electoral contestation. Different offices need to be filled by elections (measured by v2x_elecoff) AND (which, logically, suggests a multiplicative aggregation method; see Goertz 2006) these elections should not be fraudulent (measured by the remaining indicators that form part of the relevant contestation dimension). No country can be considered democratic if there are no elections, or if there are some but they are highly corrupt.

\subsubsection{Participation}

According to Gurr (1974) participation is the dimension capturing the influence attempts of the people ${ }^{15}$ As such a natural element to include in a measure of participation is the share of the population with suffrage measured by the V-Dem index v2x_suffr. ${ }^{16}$

Aside from this de jure element of participation the influence of the people in a political system is determined by de facto provisions affecting the voters ability to exercise a free and fair vote. Consequently, the following indices capturing the fairness of the elections on the voters side are also included in the participation dimension: election voter registry, v2elrgstry; election vote buying, v2elvotbuy; election other voting irregularities, v2elirreg.

As in the contestation dimension above, suffrage and the three voting participation variables are complements: no country can be considered to score high on participation without extensive suffrage, or if it has extensive suffrage but this is combined with high levels of voting irregularities, which make voting rights ineffective in practice.

\footnotetext{
${ }^{14}$ In this national election, were opposition candidates/parties/campaign workers subjected to repression, intimidation, violence, or harassment by the government, the ruling party, or their agents? (...) Other types of clearly distinguishable civil violence, even if politically motivated, during the election period should not be factored in when scoring this indicator (it is dealt with separately). (Coppedge et al., 2019b. 57).

${ }^{15}$ See Gurr (1974): 1483.

${ }^{16}$ The scores reflect de jure provisions of suffrage extension in percentage of the adult population. If the suffrage law is revised in a way that affects the extension, the scores reflect this change as of the calendar year the law was enacted, (Coppedge et al., 2019b: 43).
} 


\begin{tabular}{|c|c|c|c|c|}
\hline dimension & index & scale & $\min$ & $\max$ \\
\hline \multirow{3}{*}{$\begin{array}{l}\text { constraints on } \\
\text { the executive } \\
\text { participation }^{-}-\overline{-}^{-}\end{array}$} & v2x_jucon & interval & 0 (low constraints) & 1 (high constraints) \\
\hline & v2xlg_legcon & interval & 0 (low constraints) & 1 (high constraints) \\
\hline & $\overline{\mathrm{v}} \overline{\mathrm{x}} \overline{\mathrm{x}}-\overline{\mathrm{suffr}}$ & interval & 0 & \\
\hline \multirow{7}{*}{ contestation } & vēelrgstry & ordināal & 0 (no registry) & $\overline{4}$ (accurate registry) \\
\hline & v2elvotbuy & ordinal & 0 (vote buying) & 4 (no vote buying) \\
\hline & v2elirreg & ordinal & 0 (irregularities) & 4 (no irregularities) \\
\hline & vêelembaut & ordināil & 0 (EM $\overline{\mathrm{B}} \overline{\mathrm{B}}$ not autonomous $)$ & $\overline{4} \overline{(\mathrm{EM}} \overline{\mathrm{B}} \overline{\text { autonomous }})$ \\
\hline & v2elembcap & ordinal & 0 (EMB not capable) & 4 (EMB capable) \\
\hline & v2elintim & ordinal & 0 (strong intimidation) & 4 (no intimidation) \\
\hline & v2x_elecoff & interval & 0 (appointment) & 1 (elections) \\
\hline
\end{tabular}

Table 2: Scales of the indicators forming the dimensions

\subsection{Constructing the cube of democracy patterns}

Once the relevant indicators for each dimension are chosen, an adequate aggregation procedure needs to be selected. The question of how to aggregate the indicators into an overall index that captures the particular dimension is not trivial; the choice of aggregation method affects the content and thus the interpretation of the resulting measure. Table 2 displays the scales on which the indices are coded, their respective minima and maxima as well as their interpretation.

The two sub-indices forming the executive constraints dimensions are on the same level of abstraction. Consequently, three possible methods of aggregation seem adequate: a multiplicative method, an additive/averaging method, or a combination of the two aforementioned methods. A multiplicative aggregation ${ }^{17}$ implies complementarity between the elements, i.e. if either judicial or legislative constraints on the executive are very low and the respective index approaches zero the joint measure is very low (approaching zero) as well. Another way to combine the indices is by taking the average 18 This implies a substitutability between the indices: high judicial constraints can compensate for low legislative constraints and vice versa. In the context of defining a dimension capturing the checks on the executive complementarity as well as substitutability of the legislative and judicial constraints are equally important features. Consequently, in this paper the dimension constraints on the executive is aggregated by averaging the multiplicative as well as the additive aggregation procedure: const $=\frac{1}{2}$ const $_{\text {avg }}+\frac{1}{2}$ const $_{\text {mult }}{ }^{19}$

The indices forming the participation and the contestation dimensions are neither coded on the same scales nor with similar maximum or minimum values. The aggregation of these

\footnotetext{
${ }^{17}$ const $t_{\text {mult }}=\mathrm{v} 2 \mathrm{x}_{-}$jucon $\cdot \mathrm{v} 2 \mathrm{xlg}$ legcon.

${ }^{18}$ const $_{\text {avg }}=\frac{1}{2} \mathrm{v} 2 \mathrm{x}_{-} \mathrm{jucon}+\frac{1}{2} \mathrm{v} 2 \mathrm{xlg} \_$legcon

${ }^{19}$ This corresponds to the aggregation procedure used by V-Dem. See Coppedge et al. (2019d, p. 7).
} 


\begin{tabular}{|c|c|c|c|}
\hline model & participation & contestation & constraints \\
\hline & Suffrage & Elected Officials & Addition and \\
\hline Narrow p & & Index * latent voter & multiplication of \\
\hline & & \& candidate & legislative and \\
\hline----- & & $\overline{\text { Elected }}$ Officials $\overline{-}$ & $\bar{A} \bar{d}$ dition and $-\overline{-}_{-}$ \\
\hline & Suffrage * latent voter & Index * latent & multiplication of \\
\hline Broad participation & contestation & candidate & legislative and \\
\hline & & contestation variable & judicial constraints \\
\hline
\end{tabular}

Table 3: Overview of aggregation procedures used for each dimension in the respective models. Suffrage refers to v2x_suffr, Elected Officials Index to v2x_elecoff. The latent variables are constructed using factor analysis. Voter contestation combines the information from v2elrgstry, v2elvotbuy, and v2elirreg. Candidate contestation is constructed from v2elembaut, v2elembcap, v2elintim. The join voter \& candidate contestation variables is formed using all six contestation variables mentioned above jointly. More information on the factor analysis used to obtain these variables can be found in section $\mathrm{C}$ of the Appendix.

dimensions therefore requires more sophisticated methods than bare multiplication or averaging. Both dimensions consist of elements that are complements. To properly join them in a theory consistent manner this paper adopts the three step procedure outlined in the following.

In a first step, the ordinal indicators displayed in Table 2 are scaled between 0 and 1 by employing a cumulative distribution function transformation 20 We (adopt the V-Dem procedure and) assume the realizations of such an index $X$ are normally distributed with mean $\mu$ and variance $\sigma^{2}$. Then the standardized form of $X$ is $Z=\frac{(X-\mu)}{\sigma}$ (without loss of generality the relevant indicators are not constant). For the normalization of our data the cumulative distribution function of $\mathrm{Z}$ is used.

In a second step, for each dimension, latent variables of candidate -, voter- as well as a joint candidate \& voter contestation were created using factor analysis ${ }^{21}$

In a third step - following the complentarities/AND logic laid out above - the factor analysis output i.e. the latent variables were then multiplied with suffrage (in the broad participation model) or with the Elected Officials Index (for the contestation dimension). Table 3 provides an overview of how each dimension was aggregated in both models.

The final sample consists of 23,989 observations covering 199 countries with time series of an average length of 120.5 years.22

\footnotetext{
${ }^{20}$ To be precise, the cdf-transformation is applied twice: first to the indicators entering the factor analysis and a second time to the output of the factor analysis. Those indicators which were solely available in election years. To be precise v2elintim, v2elrgstry, v2elvotbuy, v2elirreg. were repeated over election periods (either until the next election or an electoral break (as indicated by v2x_elecreg)).

${ }^{21}$ Please find more information on the factor analysis as well as the results in Section $\mathrm{C}$ of the Appendix.

${ }^{22}$ Sections $\mathrm{D}$ and $\mathrm{F}$ of the Appendix provide detailed information on which and how many countries are included for which period.
} 


\section{The Cube of Democracy Patterns}
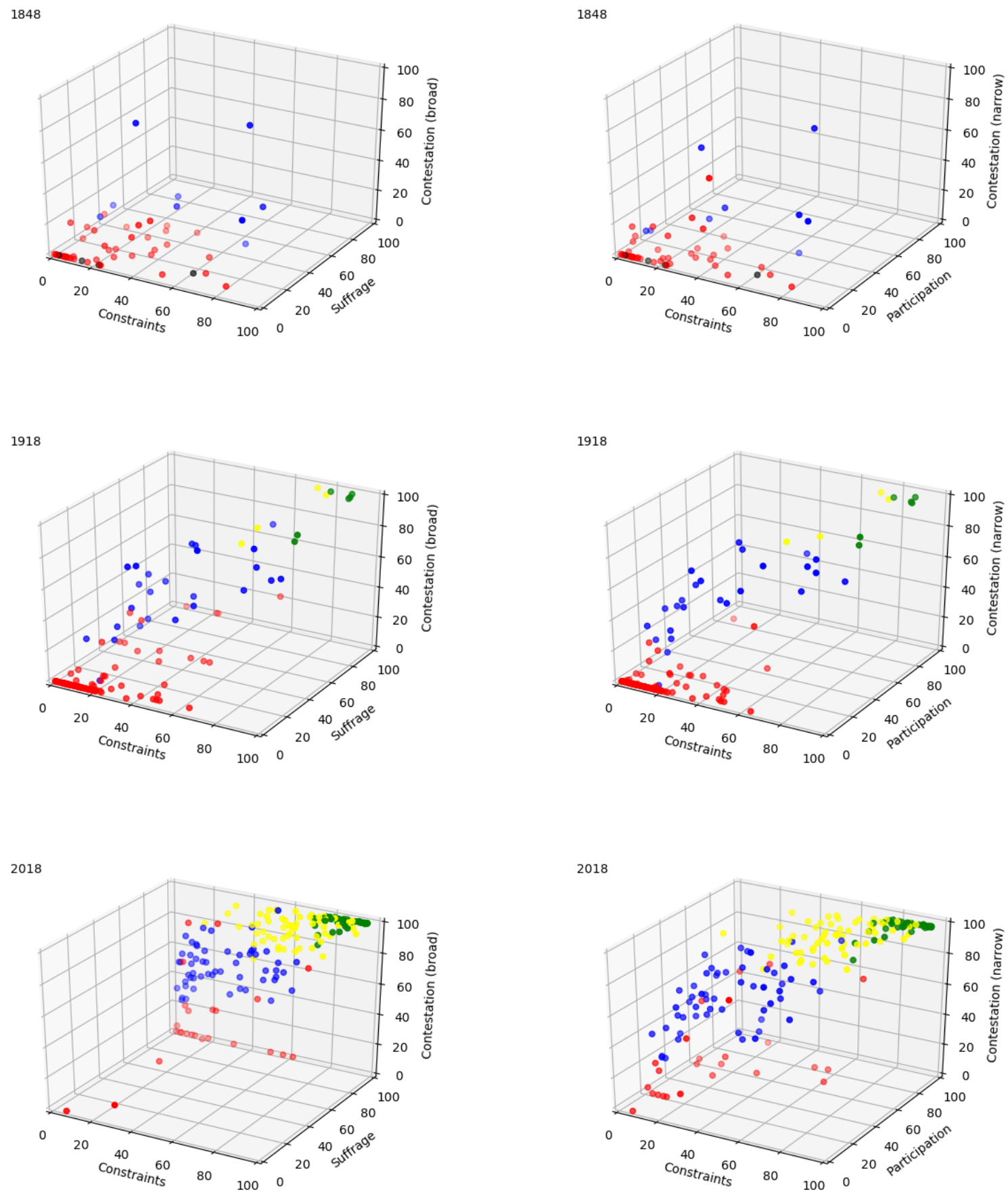

Closed autocracy Electoral autocracy

Electoral democracy Liberal democracy

Figure 3: Cube of democracy patterns for 1848, 1918 and 2018. Left: narrow participation model. Right: broad participation model. Number of countries by (year): 59 (1848), 141 (1918) and 179 (2018). Color coding by Regimes of the World Index, (Lührmann, Tannenberg, and Lindberg, 2018) 
The cube in Figure 3 display global democracy patterns in 1848, 1918, and 2018 for the narrow as well as the broad participation model along the dimensions "constraints on the executive, "participation" and "electoral contestation" ${ }^{23}$ The three dimensions span a cube covering all regime types. The observations revolve around an "axis of democracy" connecting the autocratic and democratic corners of the cube (i.e. the bottom, front, left-side and upper, back, right-side). Animated version of the cubes over time are available at http://folk.uio.no/haavas/ cube/.

Four observations should be noted. First, when considering developments over time, regimes in the autocratic corner of the cubes are not particularly stable. In fact, they are rather unstable - in the sense that they are shifting positions relatively fast - for both the narrow as well as the broad participation model. Contrary to expectations of institutional congruence following for example from Eckstein (1973) and Gurr (1974), we do not find autocratic stability.

The second observation is that "semi-democracies" are much more scattered than "pure" democracies or autocracies. In our set-up, it is possible for such intermediate regimes to be relatively democratic on one (or two) dimensions but not on all three dimensions. This result may have significance for our understanding of the nature of institutional pairing and political stability. In future work we will explore if certain pairings of institutions are more likely to lead to democratization or a lack of democratization.

The third observation is that certain parts of the cube (especially some corners) are always empty. This is not due to a conceptual flaw, but rather reflects what we would expect from, for instance, institutional congruence theory. Some constellations of institutions will never form in the first place. See Figure 3. First, note that regimes tend to be congregated into the bottom, left-hand, outer corner (autocracies) or in the upper, right-hand, back corner (democracies), and along a pathway that follows the floor, left-hand wall, and back wall. For the broad participation model, more observations occur in the interior of the cube. Four corners of the democratic cube are empty. The bottom, right-hand, front (low contestation, high constraints, low participation); upper, right-hand, front corner (high contestation, high constraints, low participation); lower, right-hand, back (low contestation, high constraints, low participation); and the upper, left-hand, front (high contestation, low constraints, low participation) corners are empty. As expected the lack of congruence in institutions prevents such regimes from forming. Note how contestation and participation go hand-in-hand.

\footnotetext{
${ }^{23}$ Section A of the Appendix provides additional cubes for each model.
} 


\begin{tabular}{|c|c|c|c|c|c|}
\hline Model & Variable & Mean & Std. Dev. & Min & $\operatorname{Max}$ \\
\hline & Electoral Democracy Index & 27.46 & 26.38 & 0.70 & 94.80 \\
\hline & Liberal Democracy Index & 22.00 & 23.08 & 0.20 & 91.40 \\
\hline \multirow{3}{*}{ Narrow participation: } & constraints & 31.93 & 28.19 & 0.23 & 97.32 \\
\hline & contestation $\overline{1}$ & $\overline{3} \overline{1} . \overline{3} 0$ & $\overline{38} \overline{13}$ & $0.00^{-}$ & $\overline{9} \overline{8} . \overline{5} \overline{8}$ \\
\hline & participation 1 & 51.82 & 44.98 & 0.00 & 100.00 \\
\hline \multirow[t]{2}{*}{ Broad participation: } & contestation 2 & $\overline{3} 1 . \overline{3} 5$ & 38.31 & $0.00^{-}$ & $\overline{9} \overline{7} . \overline{4}$ \\
\hline & participation 2 & 33.23 & 35.87 & 0.00 & 98.61 \\
\hline
\end{tabular}

Table 4: Summary statistics for Electoral \& Liberal Democracy Indices (rescaled between 0 to 100 - most democratic), and the three dimensions of the cube of democracy patterns

A fourth observation regards the pattern of change that took place from 1848 to 1918 to 2018. In 1848, no democracies existed but there was a good spatial within the left-side of the cube (i.e. limited constraints) along the floor (limited contestation) but with many countries with increasing levels of participation and suffrage. Sixty years later, a number of so-called "electoral autocracies" - as classified by Lührmann, Tannenberg, and Lindberg (2018) - had spread through the interior of the cube. In 1848 and 1918 little difference is evident between the broad and narrow participation models. One hundred years later in 2018, the number of democracies had blossomed. Now the difference between broad and narrow participation is stark. For the narrow participation model with the focus on suffrage, most regimes cluster at the "back wall". With the broad focus, more regimes lie in the interior of the cube forming an axis from the autocratic to democratic corners.

\subsection{Comparison of uni- and multidimensional variation}

Does the cube of democracy patterns capture more variation than a uni-dimensional democracy measure would? This section answers this question by comparing the variation in each of the cube's dimensions to the variation in V-Dem's Electoral Democracy Index, Polyarchy (v2x_polyarchy) and in the Liberal Democracy Index (v2x_libdem). The latter is included as a reference as it contains both Polyarchy, as well as additional components for rule of law as well as judicial and legislative constraints on the executive (the same components for constraints are included in the cube's constraints dimension).

Table 4 provides summary statistics for each of the unidimensional indices as well as for the cubes dimensions. The standard deviation along each of the cube's dimensions is higher than for unidimensional measures. It is worth noting, that the constraints dimension as well as the Liberal Democracy Index capture (to differing extents) institutional constraints on the 


\begin{tabular}{|c|c|c|c|c|}
\hline Model & Variable & Std. Dev. & Min & Max \\
\hline & Electoral Democracy Index & 18.70 & 1.49 & 82.77 \\
\hline & Liberal Democracy Index & 16.70 & 1.14 & 75.04 \\
\hline \multirow{3}{*}{ Narrow participation: } & Constraints & 21.38 & 1.53 & 83.67 \\
\hline & Contestation 1 & $25 . \overline{45}$ & 0.00 & $\overline{9} \overline{5} . \overline{6} \overline{9}$ \\
\hline & Participation 1 & 27.25 & 0.00 & 100.00 \\
\hline \multirow[t]{2}{*}{ Broad participation } & Contestation 2 & 25.64 & 0.00 & $\overline{9} \overline{5} . \overline{6} \overline{8}$ \\
\hline & Participation 2 & 22.73 & 0.00 & 95.55 \\
\hline
\end{tabular}

Table 5: Assessing variation between country means in each dimension

\begin{tabular}{|c|c|c|c|c|}
\hline & Variable & Std. Dev. & Min & Max \\
\hline & Electoral Democracy Index & 19.63 & -62.49 & 70.69 \\
\hline & Liberal Democracy Index & 16.24 & -58.64 & 67.23 \\
\hline \multirow{3}{*}{ Narrow participation: } & Constraints & 17.47 & -66.61 & 80.47 \\
\hline & Contestation 1 & $3 \overline{0} . \overline{4} \overline{2}$ & $-\overline{93.96}$ & $8 \overline{5} . \overline{1} \overline{1}$ \\
\hline & Participation 1 & 39.68 & -96.32 & 90.79 \\
\hline \multirow[t]{2}{*}{ Broad participation: } & Contestation 2 & $3 \overline{0} . \overline{6} \overline{5}$ & $-\overline{92.7 \overline{4}}$ & $8 \overline{6} . \overline{4} \overline{1}$ \\
\hline & Participation 2 & 29.97 & -91.35 & 85.74 \\
\hline
\end{tabular}

Table 6: Assessing the within country variation

executive. Such institutional frameworks are often slow changing in nature. It is therefore unsurprising that both display lower standard deviations than the other measures. The lower standard deviation on the constraints dimension (lower than for the Liberal Democracy Index) can be attributed to the fact that Polyarchy constitutes a significant component of the Liberal Democracy Index and as such is also a major driver behind its variation.

The statistics in Table 4, however, are calculated for the pooled sample. Let's take average democracy values across each country's time-series and examine the variation between these country means. Table 5 shows that country means vary to a much larger degree on each of the cube's dimensions than in the unidimensional indices. The minimum (maximum) provided in Table 5 refer to the minimum (maximum) country mean in the sample. This clearly highlights a main caveat of the narrow participation model. In the narrow participation model, the countries with the highest average values on their participation dimension had averages of 100. In that model participation is measured as suffrage. Consequently, there are 26 countries with a time series average of $100{ }^{24}$ There are also four countries with a panel mean of 0 suffrage ${ }^{25}$ It is worth noting that the time series included differ by country ${ }^{26}$ Therefore, average values of

\footnotetext{
${ }^{24}$ Armenia, Azerbaijan, Bahrain, Bangladesh, Belarus, Bosnia and Herzegovina, Cameroon, Czech Republic, Estonia, Georgia, German Democratic Republic, Israel, Kazakhstan, Kosovo, Kyrgyzstan, Latvia, Macedonia, Moldova, Pakistan, Slovakia, Slovenia, South Sudan, Tajikistan, Timor-Leste, Turkmenistan, Ukraine. ${ }^{25}$ Modena, Oldenburg, Parma and Saudi Arabia.

${ }^{26}$ See section $\mathrm{F}$ for more information on each country's time series.
} 
the time series are, of course, difficult to compare across time series spanning different periods. Therefore, we shall proceed by examining the within country variation.

How much did country values deviate from their panel mean over their respective timeseries? Table 6 supplies an assessment of the within country variation. Deviations from panel means fluctuate more on the contestation and participation dimension than in Polyarchy. That is, countries on average deviate more from their panel mean along the dimensions of the democracy cube than in a unidimensional representation. The minimum (maximum) values in Table 6 refer to the lowest (highest) deviations from a country's mean which occurred in the data.

\subsection{Case studies}

A given value on a unidimensional scale can reflect different institutional configurations. It disguises important variation. With three country examples this section shows how a multidimensional representation of democracy patterns is much more appropriate in capturing the variation across institutional configurations. The cases of Hong Kong and Ecuador illustrate the implications of chosing a unidimensional over a multi-dimensional measure for cross-country comparisons in the international system of states. The case of Azerbaijan sheds light on how a multidimensional measure is more effective in capturing variation even within one country's time series. In this section, we provide illustrative discussions and main findings for the narrow participation model only. Results for the broad participation model can be found in section $\mathrm{G}$ of the Appendix.

\section{Hong Kong and Ecuador}

In 2010, Hong Kong and Ecuador had the same value on the V-Dem Liberal Democracy index (v2x_libdem) of 0.32, which is just below the global 2010 mean (see Figure 4). However, these two countries do not look very similar at all. Figure 5 shows that while the Liberal Component index and the Electoral Democracy index are highly correlated a lot of variation remain between the two. Ecuador and Hong Kong appears to be the best candidates for a comparison. Figure 6 displays the values each country obtained on the three dimensions of the cube of democracy patterns.

Hong Kong was transferred from the UK to China in 1997 amid an agreement of a permanent political special status. V-Dem (and Freedom House) codes Hong Kong as a persistently stable semi-democracy. Hong Kong enjoys a special political status within the People's Repub- 


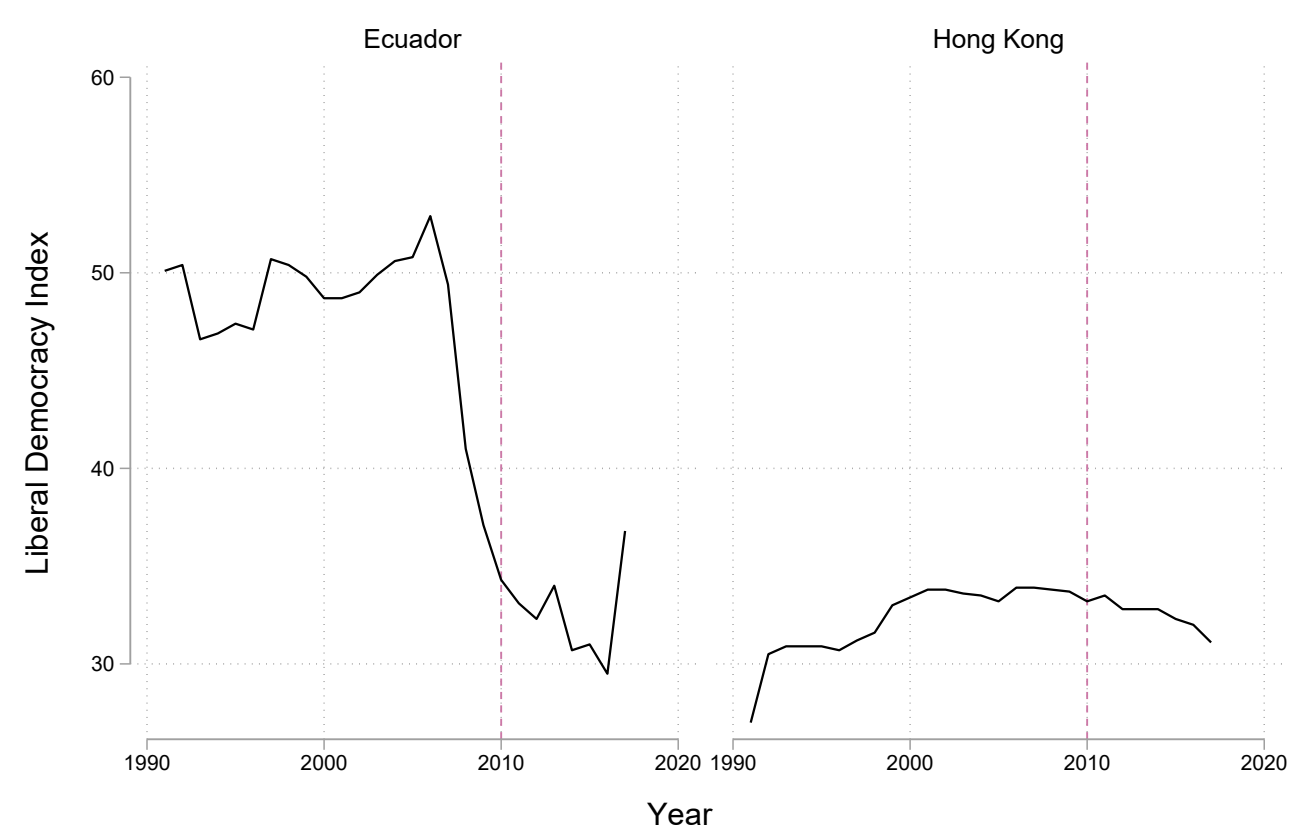

Figure 4: Liberal Democracy Index for Hong Kong and Ecuador

lic of China. The head of the executive branch is appointed by the communist party, but the selection is heavily influenced by a local Executive Council. Nevertheless, the government is not appointed by an elected body. There are limitations stemming from both other branches of government. The legislature is elected, and is empowered to check the executive power both with regard to budget, legislation and protocols of impeachment. In particular the judicial branch is seen as independent, and the appointment procedures as seen as more meritocratic than political (Rezvani, 2012).

The main short-coming of Ecuador is that the separation of powers is coded as very weak as seen in the very low coding on the constraints dimension in Figure 6. The executive branch dominates the two other branches, in particular the judicial branch, (Conaghan, 2016). A new constitution was introduced in 2008 that strengthened the executive branch at the cost of other branches. The constitution also included a number of provisions to strengthen individual and collective rights, but as the effectiveness of these provisions have been interpreted differently.

Freedom House (2017) maintain a fairly persistent coding of Ecuador, arguing that the new constitution only codified the existing practice, and hence had a limited effect. The Polity project (Marshall, Gurr, and Jaggers, 2017) do code a drop in 2008, but maintain that there remain a significant element of legislative oversight even if the nature of Ecuadorian party politics currently makes this unlikely. O'Donell (1994) highlighted Ecuador as a case of 


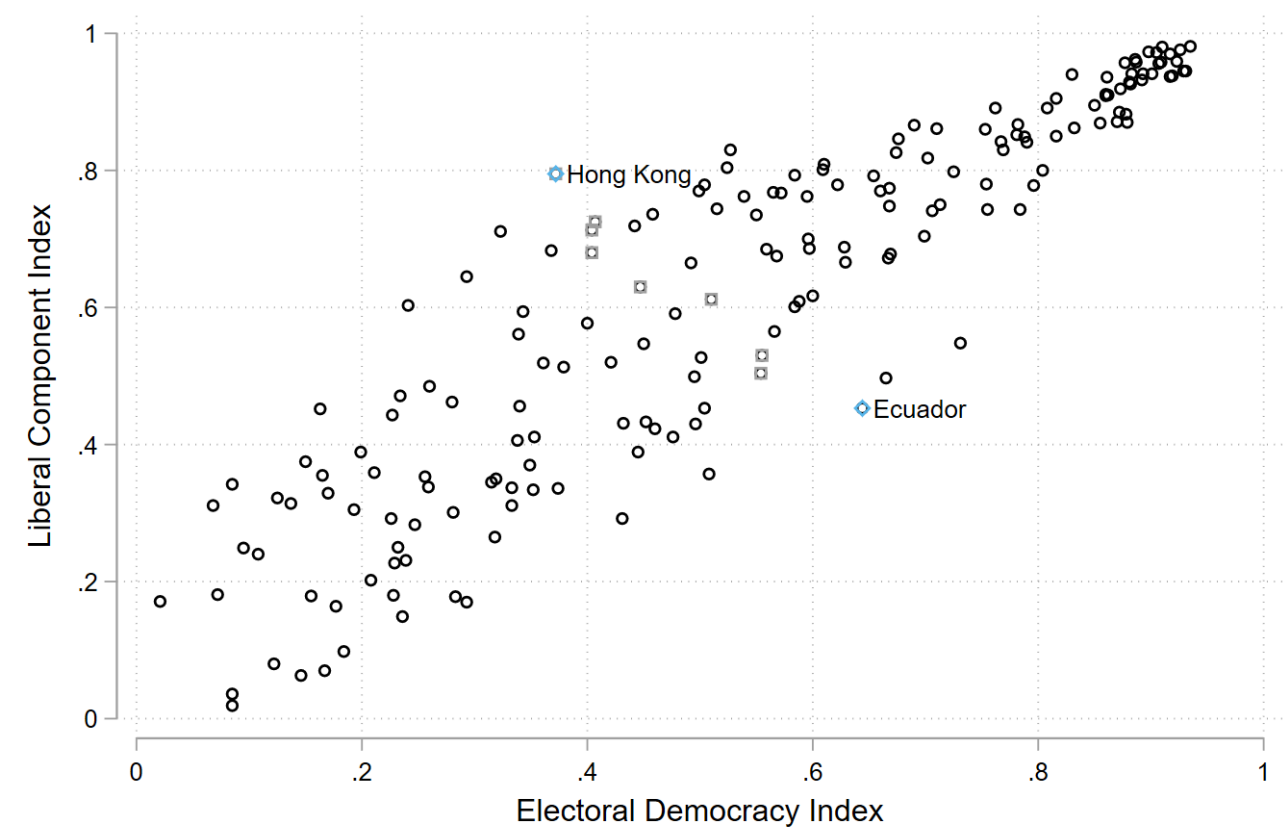

Figure 5: Liberal Component vs. Electoral Democracy

'delegative democracy', defined as a system where elected officials operate with an assumed insight into 'the will of the people' as a general justification of any political action. While often associated with left-wing ideologies, the practice is found across the political spectrum. Bestowed with an insight into the will of the people, any liberal constraints become counterproductive, whereas the legitimacy of the electoral institutions is of the utmost importance.

Unidimensional codings of these two countries cannot account for their above mentioned differences. To examine how this affects their coding in relation to other countries in the international system the Liberal Democracy Index is split into its components: the Liberal Component Index and the Electoral Democracy Index. Figure 5 illustrates this relationship. The dots are all countries in V-Dem for 2010. The boxed dots are all observations that share a Liberal Democracy Index, v2x_libdem, score of $0.32 \pm 0.02$. Ecuador and Hong Kong are the most dissimilar of these. Hong Kong is rated as quite liberal, but with limited participation, whereas Ecuador scores reasonably well on competitive political participation but not as well on the liberal freedoms. The Liberal Democracy Index value of 0.32 does therefore not correspond to a specific institutional setup but rather to a range of setups with differ quite a lot. This shows that multidimensional indices of democracy are necessary to provide a valid indicator. 


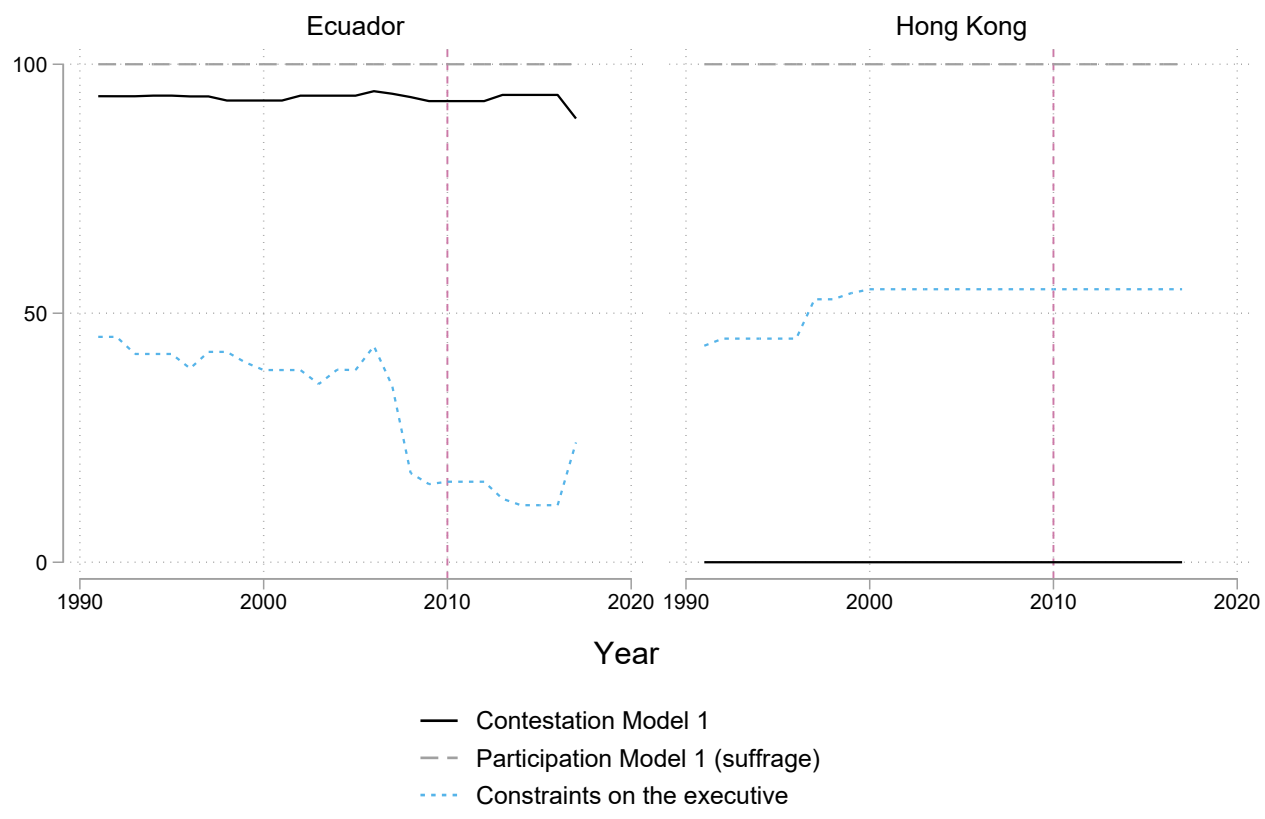

Figure 6: Narrow participation model: contestation, participation and constraints for Ecuador and Hong Kong

\section{Azerbaijan}

Collapsing information into one dimension can make countries appear similar that are in fact not. Also, a unidimensional measure can fail to account for variations in the level of democracy both between two countries, but also within a single country. Azerbaijan serves as a good example of how a country can be stable in some dimensions and not in others. Figure 8 shows the three dimensions for Azerbaijan between 1990 and 2018. Narrow participation remains stable and high for the whole period, whereas constraints on the executive is more or less nonexistent from 1995 and onwards. The contestation dimension is declining in the whole period, with three distinct breaking points where the score drops significantly from one year to the next.

When collapsed into a single dimension, Azerbaijan seems to be a fairly stable semidemocracy for the whole period, declining by only a few points over the 1995 - 2018 period. As the multi-dimensional model shows, this stability is an artifact of the aggregation into a single dimension. Azerbaijan has been very stable in two dimensions and very unstable in one. The effect of the decline in contestation is of great substantial interest, but this is lost in the scores for the aggregated, unidimensional measure. 


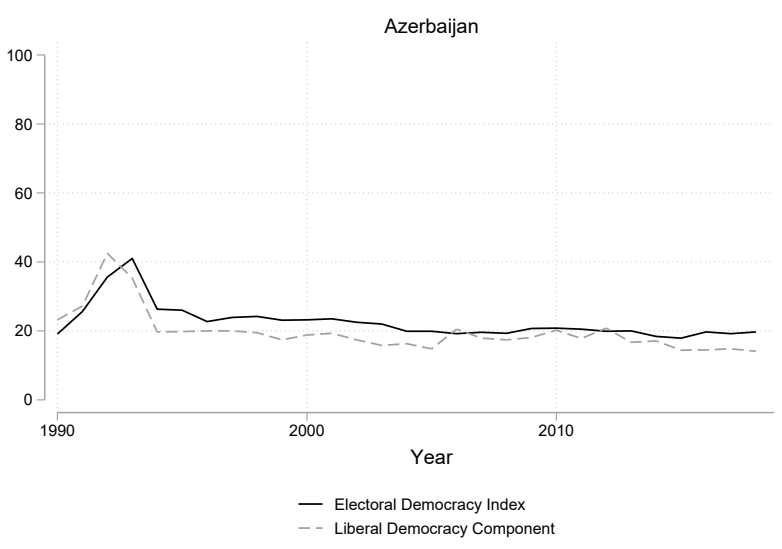

Figure 7: Comparing Electoral Democracy Index and Liberal Democracy Component for Azerbaijan

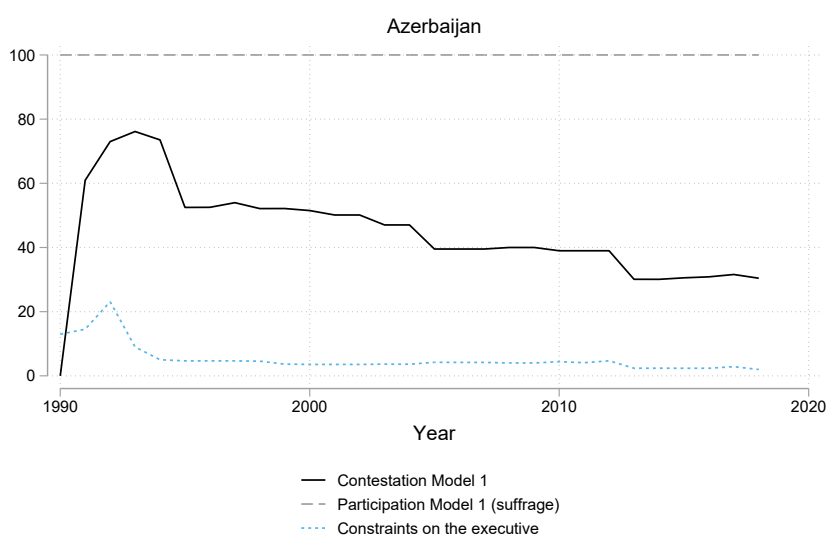

Figure 8: Narrow participation model: contestation, participation and constraints for Azerbaijan

Figure 7 displays the Electoral and Liberal Democracy Indices for Azerbaijan. In particular on the Liberal Democracy Index Azerbaijan seems to have gone through a very steady gradual downward process since 1995. Taking a closer look at the three dimensions of the cube shows that this process in reality was not steady, but rather that distinct downward movements occurred on different dimensions across different points in time (see Figure 8).

Azerbaijan became independent after the demise of the Soviet Union, and an initial democratic experiment met an immediate security crisis over the ethnic Armenian enclave Nagorno-Karabakh, and by the mid-1995s the country was no longer democratic by any means. The 1990s setback was visible across all three dimensions. Nonetheless, for the last 20 years, Azerbaijan has been fairly stable solely on the constraints dimension. Figure 8 shows variation (and sudden downward movements) on both dimensions, contestation and participation, occurring at different points in time. This variation is lost in a unidimensional representation.

The term 'hegemonic authoritarianism' has been used to describe this kind of development, (Hyde and Marinov, 2012), where the outcome of elections become more and more certain in advance to the point where the incumbent is in full control. This control manifests itself through a number of mechanisms. Voters and opposition elites are coopted into the regime. This can happen through direct payments, but also through specific targeted government interventions that can be removed on short notice. Vote buying is expensive, but Azerbaijan has a steady income from oil. Figure 3 reveals something interesting. When the oil price was stable above $\$ 100$ /barrel between 2011 and 2013, Azerbaijan became more autocratic along all axes. 
A different, but equally effective strategy is to make sure the opposition is severely fragmented, and that these opposition parties spend as much time attacking each other as the incumbent. Azerbaijan has been highly successful in fragmenting the opposition, and in 2018, no less than 7 candidates shared the $14 \%$ of the vote not received by president Aliyev ${ }^{27}$

Fraudulent elections constitute another mechanism. Holding elections, stuffing the ballots and ignoring the consequences may be a show of strength. The blatant snub of any democratic ideals while still actually holding elections demonstrates the total control the incumbent enjoys. Azerbaijan has seen a deterioration of electoral integrity with no corresponding increase in political oppression, a clear indication of how the Azerbaijani opposition and civil society has been rendered impotent by the regime. This illustrates perfectly how political participation has become meaningless in this country.

\subsection{Regional variation since the French Revolution}

We now turn to discussing trends in the three dimensions of democracy from 1789 to the present, both considering the global averages on these dimensions as well as averages for the six major world regions (Eastern Europe and Central Asia; Latin America and Caribbean; Middle East and North Africa; Sub-Saharan Africa; Western Europe and North America; Asia). We focus our discussion on the first three-dimensional operationalization laid out above for the so-called "Narrow participation model". To reiterate, this model distinguishes between narrowly defined participation (suffrage), broadly defined contestation (both voter- and candidate-/party-related measures), and constraints on the executive. Figures displaying global and regional trends for the alternate operationalization - broadly defined participation, narrowly defined contestation (only candidate-/party-related measures), and constraints on the executive - are placed in the Appendix.

While both the narrow and broad participation models are conceptually relevant for capturing different notions of democracy, one interesting aspect of focusing on the narrow participation model, is the greater divergence in global and regional trends for the different dimensions. Especially after WWI, globally, there has been a dramatic increase in participation - when focusing narrowly on suffrage rights - which has far outpaced the improvement in other democracy dimensions. This increase reflects franchise expansions even in countries, from different regions, where other aspects of democracy were more or less absent (e.g. Com-

\footnotetext{
${ }^{27}$ Source: http://www.electionguide.org/elections/id/3051/
} 
munist countries in Eastern Europe after WWII). What is more, narrow participation displays a close to monotonic, global trend across modern history, defying downturns even during the so-called "reverse waves" of democratization (Huntington, 1991). Observed trends are more similar for, e.g., contestation and participation broadly construed (see Appendix Figure 17 for global trends), as de facto indicators moderating the exercise of voting rights, such as accurate voting registries, have moved more in tandem with other aspects of free and fair elections than suffrage rights have. Hence, we opt to discuss the multi-dimensional operationalization where divergences in trends between dimensions are the most noticeable.

Figure 9 maps the global average scores for the three dimensions on a regular twodimensional cartesian coordinate system, starting in 1789 and ending in 2018. All dimensions are normalized to a 0-100 scale. We plot the mean scores for all polities - sovereign countries, semi-autonomous polities (e.g., Norway under the Swedish-Norwegian Union and Hungary under the Dual Monarchy of Austria-Hungary), and colonies - with available data in the given year. Given the changing number of polities with data on these measures across modern history, the sample composition changes considerably over time, from 41 polities in 1789 to 179 polities in 2018. Most notably, the sample more than doubles from 1899 (52 polities) to 1900 (111 polities) ${ }^{28}$. Thus, we demarcate this year with a vertical line. Since participation, contestation, and constraints on the executive were typically much lower in these Asian and African colonies that enter the sample in 1900, this explains the substantial drops in the average global scores mapped in Figure 9 for this year.

Nonetheless, even when disregarding changes in the scores that are due to the changing sample, there are clear patterns in the global averages of the three dimensions across modern history. In this regard, we make several observations about the developments of the three dimensions, in particular focusing on patterns that one will not observe when only using a standard, one-dimensional summary measure of democracy instead of our multi-dimensional approach:

First, the overall expansion in democracy, globally, has been uneven across our three dimensions when we consider the entire time interval. In particular, we noted that participation,

\footnotetext{
${ }^{28}$ This expansion is related to the fact that the "Historical" part of the V-Dem time series covers far fewer colonies in Asia and Africa than the post-1900 part of the time series (see Knutsen et al., 2019). For most other years, the sample composition is either identical to the prior year, or changes by only 1-2 polities. Exceptions are the end of WWI, where the sample changes from 136 polities in 1917 to 141 in 1918 and 144 in 1919, as well as the end of the Cold War and the dissolution of the Soviet Union and Yugoslavia, where the sample changes from 154 polities in 1989 to 165 in 1990 and 169 in 1991 . For the exact time series of each polity included in V-Dem, we refer to the V-Dem Country Units document (Coppedge et al., 2019c)
} 


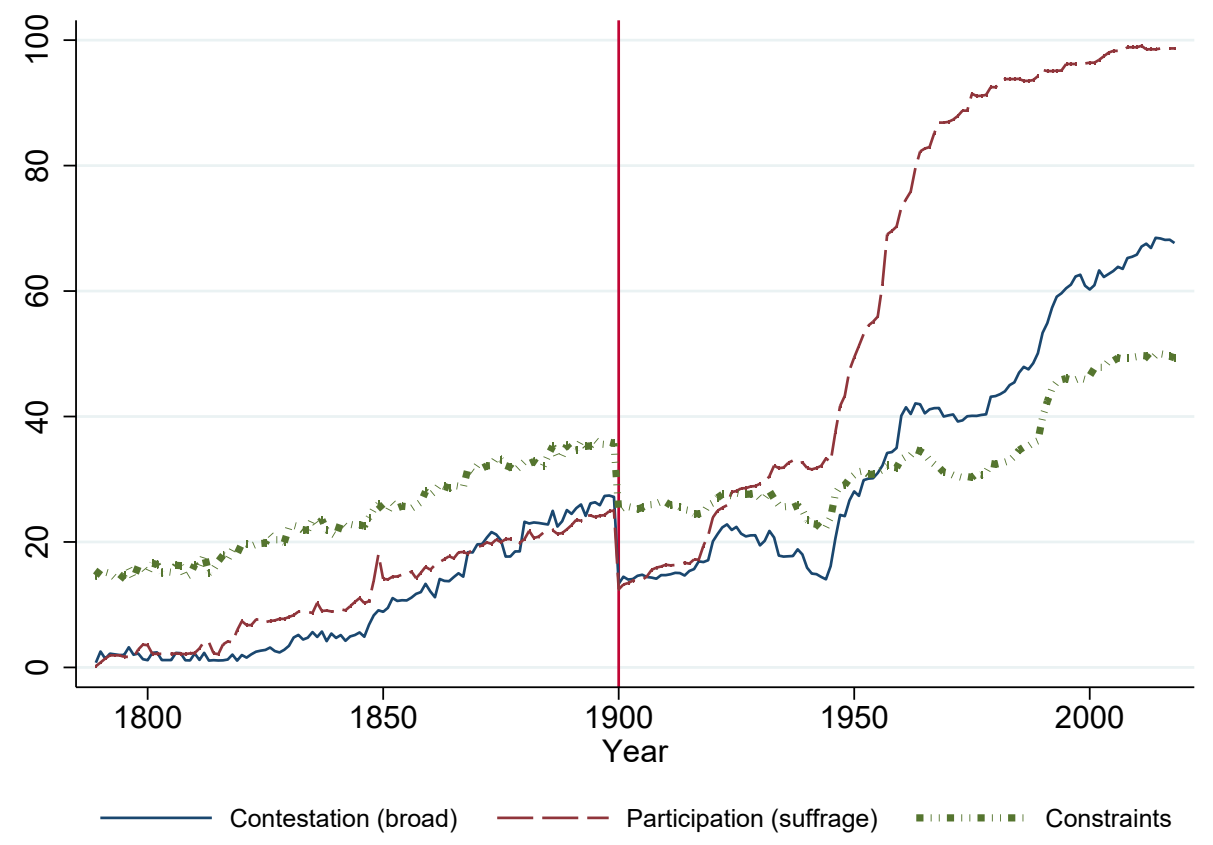

Figure 9: Global average participation (narrow), contestation (voters + candidates/parties), and constraints, 1789-2018. The vertical line marks the major expansion of the sample from year 1899 to year 1900, notably adding a number of African and Asian colonies.

as measured by suffrage, has witnessed a much steeper increase than contestation and, in particular, constraints. In the year 1789, the average participation score was only 0.2 whereas it was 98.7 in 2018. This 98.5 point increase reflects the dramatic expansion in voting rights, globally, that took place throughout modern history (see also, e.g., Knutsen et al., 2019), and in particular after the end of WWI. In 1789, only a couple of countries with data (United Kingdom and Poland) provided suffrage to some portion of their adult citizens, and in the last decade only a few countries fail to provide de jure voting rights to their entire adult population (Saudi Arabia, Somalia, United Arab Emirates). In contrast, contestation changed by 54.0 points (from 19.6 in 1789 to 73.6 in 2018) and constraints "only" by 34.8 points (from 14.6 in 1789 to 49.4 in 2018). Concerning constraints, the modest development across time reflects that several non-electoral regimes placed extensive legislative and/or judicial constraints on their executive even in the late-18th century (e.g., Sweden) and that several electoral regimes only have weak such constraints even today (e.g., Cuba, Russia, and Turkey). In sum, our multi-dimensional approach allows us to pinpoint that the global advance of democracy across modern history has been uneven, in the sense that the advance has been more marked in certain areas than in others. 
Second, the observation made by Samuel Huntington (1991) that democratization, globally, has not advanced in a straightforward, monotonic fashion, but rather followed several "waves" and "reverse waves" of democratization, is also more nuanced when taking our multidimensional approach. Specifically, two of our dimensions - contestation and constraints - seem to follow Huntington's original classification of waves and reverse waves fairly well, whereas participation follows a somewhat different trajectory. Disregarding the drop in 1900, which is due to the above-noted expansion of the sample, contestation and constraints followed a fairly consistent upward trajectory all the way from 1789 to the 1920s, a time period corresponding to Huntington's long first wave, before stagnating and even declining in the interwar period (the first reverse wave). Further,these two dimensions observed substantial increases - although contestation much more so than constraints - in the aftermath of WWII and to about 1960, before Huntington's second reverse wave sets in with declining scores until the start of the third wave around the mid-1970s. In contrast, participation has, with the notable exception of the period around 1850, been consistently increasing, even across Huntington's reverse waves of democratization. Indeed, some of the sharpest increases in participation came during the early part of the interwar period, when the other dimensions stagnated or regressed, and from after WWII and well into the second reverse wave, with the expansion of de jure voting rights also to female adults in many countries.

Third, our multi-dimensional approach allows us to identify several nuances and differences between the dimensions when it comes to short-term developments during various, specific time intervals. For example, the revolutionary years of 1848 and 1849 (see, e.g., Rapport 2008) were marked by notable upturns in democracy, globally, but mainly when considering participation and contestation, and far less so when it comes to constraints. Contestation increased from 31.3 in 1847 to 40.0 in 1849 , whereas participation increased from 10.6 to 18.1. In contrast, constraints only changed from 23.9 to 26.0. The 1848 revolutions, which took place mainly in Europe, were associated with improvements in voting rights and the introduction or improvement of contested multi-party elections in many countries, but failed to impose additional legislative or judicial constraints on the chief executive. One other interesting nuance is that whereas participation quickly regressed with the subsequent counter-revolutions (from 18.1 in 1849 to 14.0 in 1851), the global average in contestation did not fall much (from 40.0 in 1849 to 38.7 in 1851). Yet another nuance is that the global improvement in democracy after WWII was more marked for contestation (and much more marked for participation) than for constraints. 

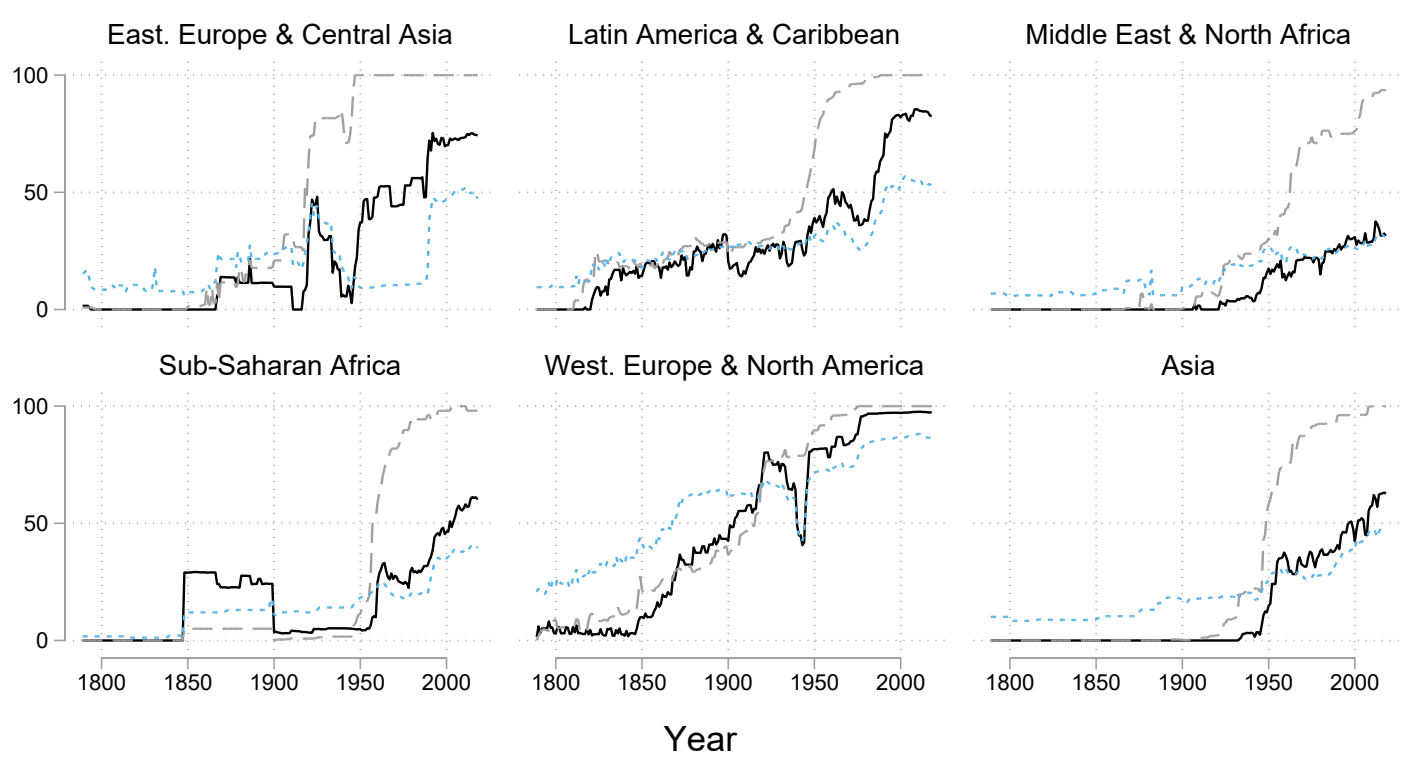

- Contestation (broad)

- - Narrow participation (suffrage)

.... Constraints on the executive

Figure 10: Narrow participation model: average participation (suffrage), contestation and constraints on the executive across World regions, 1789 - 2018

The global average for contestation increased from 44.3 in 1946 to 55.9 in 1959, whereas the corresponding change for constraints was from 27.7 to 31.9. Such nuances are impossible to detect with a unidimensional democracy measure.

The benefits of using a multi-dimensional approach also becomes clear when considering various regions of the world, either when it comes to detecting more refined developments over time within each particular region or when it comes to comparing "typical regimes" across different regions. Figure 10 displays regional averages for our three dimensions for the narrow participation model in the six major world regions listed above (Appendix $\mathrm{H}$ contains similar plots for the broad participation model).

Regarding comparisons across regions, most extant unidimensional measures of democracy would place the Western Europe and North America (WENA; 24 polities) at the top and Middle East and North Africa (MENA; 21 polities) towards the bottom. This is, for example, the case with V-Dem's Liberal Democracy Index when we consider regional averages for the year 2018 (Coppedge et al., 2019a). WENA obtains an average score of 0.78 whereas the corresponding number for MENA is only 0.19. All other regions have average Liberal Democracy scores ranging from 0.31 (Sub-Saharan Africa; 51 polities) to 0.48 (Latin America and Caribbean; 
25 polities). When using our multi-dimensional approach, we obtain similar results: WENA is the highest-scoring region on all three dimensions in 2018 - 97.3 on contestation, 100.0 on participation, and 86.0 on constraints - whereas MENA is lowest on all three dimensions - 58.0 on contestation, 93.6 on participation, 31.2 on constraints. Other differences between regions that would be lost when using a unidimensional approach are also evident. For example, at present (2018) Eastern Europe and Central Asia score higher than Asia on contestation (75.0 vs. 72.6), but the rank ordering of these two regions is reversed for constraints (48.2 for Eastern Europe and Central Asia vs. 48.4 for Asia) 29

Nevertheless, the benefits of the multi-dimensional approach in terms of detecting nuances become even more clear when we consider regime developments over time in the different regions of the world. For example, unidimensional measures, such as V-Dem's Liberal Democracy Index, show a notable increase around the fall of the Berlin Wall and the collapse of the Soviet Union, with the average regional score being 0.08 (10 countries) in 1988 and 38.0 (26 countries) in 1992. Yet, Figure 10 shows that whereas the change was notable on (judicial and legislative) constraints on the executive (from 11.6 in 1988 to 47.9 in 1992), participation, defined in terms of suffrage, did not move at all. In fact, Eastern Europe and Central Asia was the first region in the world to obtain a perfect 100-score on our narrow participation measure, already in 1947 , whereas the "democratic beacon" of WENA only achieved this perfect average score in 1975 .

To take another example, Sub-Saharan Africa is widely believed to have been hit particularly hard with the second reverse wave of democratization (Huntington 1991), as several early post-colonial, multi-party regimes faced either coups d'état by military officers or self-coups by former liberation heroes leading these new countries right after decolonization (see, e.g., Meredith 2007). The regional average for V-Dem's Liberal Democracy Index peaked in 1963 at 0.133. At the beginning of the third wave, in 1974, the score had sunk to 0.116. Yet, this change masks the fact that, according to our measures, participation (narrowly defined as suffrage) increased from 70.3 to 84.8 during this time period. In contrast, the scores mapped in Figure 10 reveal that contestation observed a steep decline from a fairly high level (from 51.7 to 39.9) whereas constraints did the same from a relatively low initial level (from 25.4 to 18.4). These are only some of the interesting, and more detailed, regional patterns that democracy scholars may detect once moving from only studying unidimensional democracy indices to employing a multidimensional measurement strategy.

\footnotetext{
${ }^{29}$ To be precise, "Asia" here refers to Asian countries that are neither part of the Middle East nor one of the old Soviet Republics located in Central Asia.
} 


\subsection{Patterns of similarity-dissimilarity in the cube of democracy over time}

The democracy cube, displayed above in Figure 3, can be animated to show how the distribution of patterns of regimes changes over time ${ }^{30}$ At some points in time we see a much greater spread of regime-dots than at other points in time, while at the same time there also appears to be areas of the cube that almost always empty. These patterns correspond to the degree of similar (crowded spaces in the cube) and dissimilar (dispersed regimes throughout the cube) types or regimes. We assess how this spread of regimes in the cube-space changes over time.

To more precisely evaluate the degree of global regime similarity-dissimilarity, we calculate a GINI, a standard inequality estimate, that illustrates how evenly spread the dots are across the space of the cube. To this end, we divide the cube up into 125 quadrants and then calculate the evenness of the spread of observed regimes, in a given year, across these quadrants. In a world in which every regime in a year is found in the same quadrant, the GINI measuring the level of regime similarity in the world would be 1; if no quadrant contains more than 1 regime, the GINI would be 0. Figure 11 shows this GINI, the pattern of regime similarity-dissimilarity, over time ${ }^{31}$

The first thing to note is the y-axis, this only spans from 0.7 to 1 and across the time period similarity in regime-space never falls below 0.76. In other words, over the period for which we have data. ${ }^{32}$ the level of similarity, though fluctuating, has remained high. This, in turn, means that most of the possible combinations of contestation, competition, and suffrage are, simply, not observed. Several different ways in which people could constitute a regime which are never ever used. Instead we see a strong global convergence whereby most regimes are similar to each other.

This is especially true across the first almost 50 years for which we have available data. In this long period, most regimes would fall towards the most authoritarian corner of the cube - this means that in this period not only were most regimes non-democratic most of these authoritarian states were non-democratic in the same way, they exhibited the same combination

\footnotetext{
${ }^{30} \mathrm{An}$ animated version of the cube can be seen online here: ANONYMIZED WEBPAGE.

${ }^{31}$ In the narrow participation model the (almost global) adoption of full suffrage after 1990 leads to the vast majority of regime dots being located on the cube's back wall (i.e. where suffrage $=100$ ), which skews the GINI and collapses precisely the variation in regime dots that we seek to explore here. Therefore, this section, and hence Figure 11, discusses the results for the broad participation model.

${ }^{32}$ As discussed in the previous section the number of countries sharply increases with the year 1900. For that reason we limit our GINI analysis to the timespan 1900 - 2018.
} 


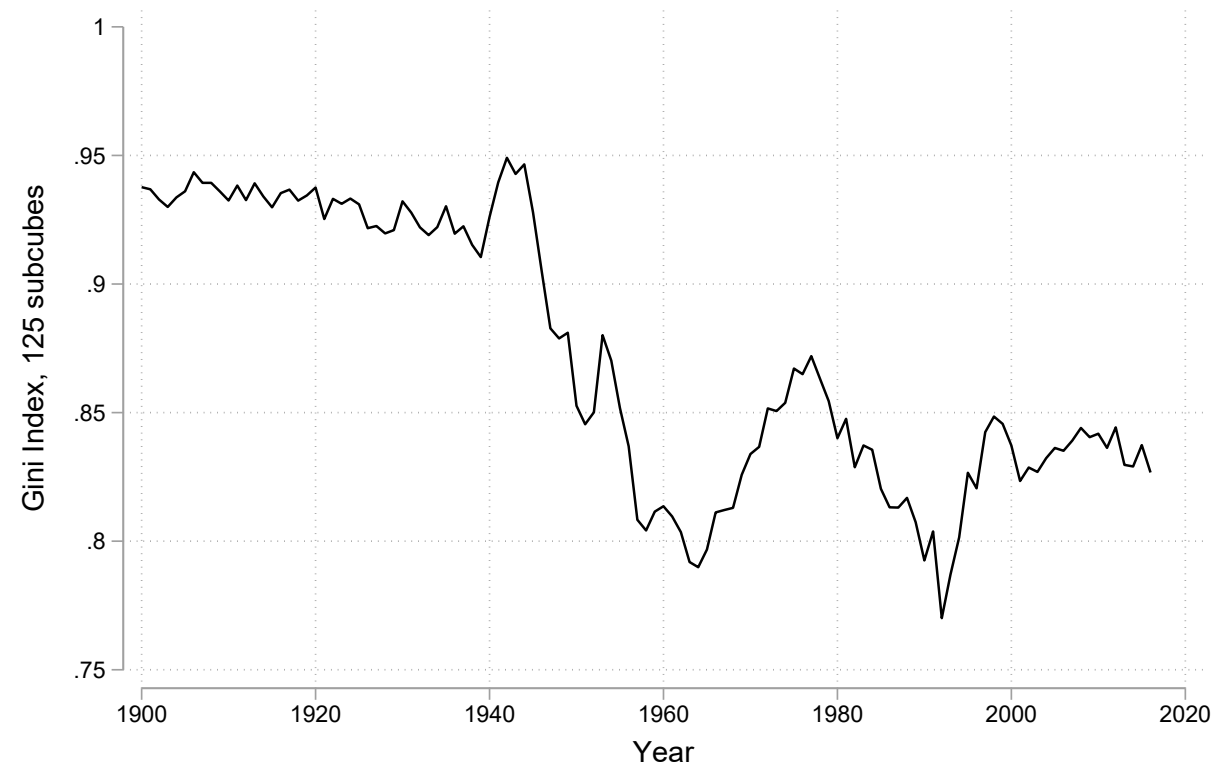

Figure 11: A GINI measure of regime similarity-dissimilarity in the democracy cube according to the Broad Participation Model, 1900 to 2018

of low contestation, low suffrage, and low competition. Up to and including World War 2, we even see an increase in similarity as some of the few democracies at the time revert to autocratic rule. Following WW2, however, we see a pronounced decline in similarity (or an increase in dissimilarity), as the GINI falls from 0.95 in 1945 to below 0.8 in 1959.

The fall in similarity is the result, mainly, of a strong trend towards democratization. This process pushes countries from the authoritarian corner to the democratic corner. There is some evidence, exhibited by the fall in similarity (rise in dissimilarity), that the pattern by which countries make this journey is heterogenous, countries become democratic in different ways in the sense that they do not move in parallel along the contestation, suffrage, and competition dimensions. As a result, as long as a sizable amount of countries are undergoing this transformation, similarity in regime types declines and more of the cube space is covered.

As more countries move firmly up into the democratic corner, however, we again see a tendency, especially after the mid-1990s, by which countries have become democratic and they are democratic in the same way. The level of similarity today is lower than it was in the early 1900s not because we have many more different configurations of regimes, but because we now have a split between a sizable amount of democracies and a sizable amount of autocracies compared with mainly autocracies in the early 1900s. There are some potentially important implications of this. The regime space we conceptualise, as well as the way in which many 
theories of regimes conceptualise different dimensions of regimes, has failed to really account for, let alone explain, the strong global convergence, gravity, we see in regime configurations. Why are so we combinations of contestation, suffrage, and competition observed? Is this an important indication of global diffusion and spread of norms and ideas about governance and government? Is it simply an historical artifact? These are important questions that we leave to be addressed by future research.

\section{Conclusion}

This article posits that the concept of democracy is inherently multidimensional. It proposes a three-dimensional conceptualization of democracy based on V-Dem data, leading to a regime in a given year being represented by a dot in cube of democracy patterns. Employing such a multidimensional visualization provides several interesting insights:

First, we observe that global and regional average regime characteristics change along different dimensions during different historical periods. Global variation in regime configurations is changing substantially over time (at some points regime configurations tend to converge whereas at other times they diverge from one another).

Second, using our multidimensional conceptualization we provide further evidence that unidimensional indicators of democracy collapse and combine "too much" relevant information in one index. Indeed, the cube of democracy patterns captures more variation on each of its dimensions than comparable unidimensional measures.

Third, we also can distinguish between institutional configurations that appear similar on a unidimensional measure but are in reality quite different (for example Hong Kong and Ecuador).

Furthermore, the cube of democracy shows that certain configurations of political institutions never occur. In other words, some institutional arrangements simply do not exist. We find no regimes that possess: high levels of participation (or suffrage) and constraints with low levels of contestation; low levels of participation and contestation with high levels of constraints; high levels of contestation and constraints with low levels of participation; high levels of contestation with low participation and constraints. Four corners of the democratic cube are empty. In contrast, "pure autocratic regimes" that exhibit similar low rankings in terms of participation, contestation, and constraints abound. There are also numerous "pure democ- 
racies" also exhibit coherence with high levels of participation, contestation, and constraints. There are also several regimes that have high levels of participation and contestation, but lack in terms of constraints.

The focus of this article is on the multidimensional conceptualization of democracy/institutional configurations on a macro-level. Going forward, such a conceptualization will allow for much more detailed inference on a broad range topics. Examples might include the dynamic relationships between more specific clusters of institutions, on the one hand, and development, conflict, or trade, on the other. Hence, the multidimensional conceptualization measurement strategy provided here lays the basis for several future studies.

\section{Further acknowledgements}

With the exception of Figures 3, 12, and 13 all Figures were created using stata colorscheme plotplainblind by Bischof et al. (2017).

\section{References}

Acemoglu, Daron, Suresh Naidu, Pascual Restrepo, and James A Robinson (2019). "Democracy does cause growth". In: Journal of Political Economy 127.1, pp. 47-100.

Bischof, Daniel et al. (2017). "New graphic schemes for Stata: plotplain and plottig". In: Stata Journal 17.3, pp. 748-759.

Boese, Vanessa A (2019). "How (not) to measure democracy". In: International Area Studies Review 22.2, pp. 95-127.

Cheibub, José Antonio, Jennifer Gandhi, and James Raymond Vreeland (2010). "Democracy and dictatorship revisited". In: Public choice 143.1-2, pp. 67-101.

Conaghan, Catherine M (2016). "Ecuador Under Correa". In: Journal of Democracy 27.3, pp. 109-118.

Coppedge, Michael, John Gerring, David Altman, Michael Bernhard, Steven Fish, Allen Hicken, Matthew Kroenig, Staffan I Lindberg, Kelly McMann, Pamela Paxton, et al. (2011). "Conceptualizing and measuring democracy: A new approach". In: Perspectives on Politics 9.2, pp. $247-267$. 
Coppedge, Michael, John Gerring, Carl Henrik Knutsen, Staffan I Lindberg, Jan Teorell, David Altman, Michael Bernhard, M Steven Fish, Adam Glynn, Allen Hicken, Anna Lührmann, Kyle L. Marquardt, Pamela McMann Kelly Paxton, Daniel Pemstein, Brigitte Seim, Rachel Sigman, Svend-Erik Skaaning, Jeffrey Staton, Agnes Cornell, Lisa Gastaldi, Haakon Gjerløw, Valeriya Mechkova, Johannes von Römer, Aksel Sundström, Eitan Tzelgov, Luca Uberti, Yi-ting Wang, Tore Wig, and Daniel Ziblatt (2019b). V-Dem Codebook V9.

Coppedge, Michael, John Gerring, Carl Henrik Knutsen, Staffan I Lindberg, Jan Teorell, David Altman, Michael Bernhard, M Steven Fish, Adam Glynn, Allen Hicken, Anna Lührmann, Kyle L. Marquardt, Kelly McMann, Pamela Paxton, Daniel Pemstein, Brigitte Seim, Rachel Sigman, Svend-Erik Skaaning, Jeffrey Staton, Steven Wilson, Agnes Cornell, Lisa Gastaldi, Haakon Gjerløw, Nina Ilchenko, Joshua Krusell, Laura Maxwell, Valeriya Mechkova, Juraj Medzihorsky, Josefine Pernes, Johannes von Römer, Natalia Stepanova, Aksel Sundström, Eitan Tzelgov, Yi-ting Wang, Tore Wig, and Daniel Ziblatt (2019a). V-Dem Dataset v9. Coppedge, Michael, John Gerring, Carl Henrik Knutsen, Staffan I Lindberg, Jan Teorell, Vlad Ciobanu, and Lisa Gastaldi (2019c). V-Dem Country Coding Units v9.

Coppedge, Michael, John Gerring, Carl Henrik Knutsen, Staffan I Lindberg, Jan Teorell, Kyle L. Marquardt, Juraj Medzihorsky, Daniel Pemstein, Josefine Pernes, Johannes von Römer, Natalia Stepanova, Eitan Tzelgov, Yi-ting Wang, and Steven Wilson (2019d). V-Dem Methodology $v 9$.

Dafoe, Allan, John R Oneal, and Bruce Russett (2013). "The democratic peace: Weighing the evidence and cautious inference". In: International Studies Quarterly 57.1, pp. 201-214.

Dahl, Robert Alan (1971). Polyarchy: Participation and opposition. Yale University Press, New Haven and London.

Diamond, Larry (1994). Political culture and democracy in developing countries: Textbook edition. Lynne Rienner Publishers.

Eckstein, Harry (1973). "Authority patterns: A structural basis for political inquiry". In: American Political Science Review 67.4, pp. 1142-1161.

Freedom House (2017). "Freedom in the World 2016: Anxious Dictators, Wavering Democracies: Global Freedom under Pressure". In: Available at: https: // freedomhouse.org/ sites/default/files/FH_FITW_Report_2016.pdf (accessed on Dec. 1, 2017). 
Gates, Scott, Håvard Hegre, Mark P. Jones, and Håvard Strand (2006). "Institutional inconsistency and political instability: Polity duration, 1800-2000". In: American Journal of Political Science 50.4, pp. 893-908.

Goertz, Gary (2006). Social science concepts: A user's guide. Princeton University Press, Princeton, New Jersey, USA.

Gurr, Ted Robert (1974). "Persistence and change in political systems, 1800-1971". In: American Political Science Review 68.4, pp. 1482-1504.

Henderson, Errol Anthony (1998). "The democratic peace through the lens of culture, 18201989". In: International Studies Quarterly 42.3, pp. 461-484.

Huntington, Samuel P. (1968). Political Order in Changing Societies. New Haven, CT: Yale University Press.

- (1991). "Democracy's third wave". In: Journal of democracy 2.2, pp. 12-34.

Hyde, Susan D and Nikolay Marinov (2012). "Which elections can be lost?" In: Political Analysis 20.2, pp. 191-210.

Knack, Stephen (2004). "Does foreign aid promote democracy?" In: International Studies Quarterly 48.1, pp. 251-266.

Knutsen, Carl Henrik and Håvard Mokleiv Nygård (2015). "Institutional Characteristics and Regime Survival: Why Are Semi-Democracies Less Durable Than Autocracies and Democracies?" In: American Journal of Political Science 59.3, pp. 656-670.

Knutsen, Carl Henrik, Håvard Mokleiv Nygård, and Tore Wig (2017). "Autocratic elections: Stabilizing tool or force for change?" In: World Politics 69.1, pp. 98-143.

Knutsen, Carl Henrik, Jan Teorell, Tore Wig, Agnes Cornell, John Gerring, Haakon Gjerløw, Svend-Erik Skaaning, Daniel Ziblatt, Kyle L Marquardt, Daniel Pemstein, and Brigitte Seim (2019). "Introducing the Historical Varieties of Democracy dataset: Political institutions in the long 19th century". In: Journal of Peace Research 56.3, pp. 440-451. Dor: 10.1177/ 0022343318823866 .

Levitsky, Steven and Lucan A Way (2010). Competitive authoritarianism: Hybrid regimes after the Cold War. Cambridge University Press.

Li, Quan and Rafael Reuveny (2006). "Democracy and environmental degradation". In: International studies quarterly 50.4, pp. 935-956. 
Lührmann, Anna, Marcus Tannenberg, and Staffan I Lindberg (2018). "Regimes of the World (RoW): Opening New Avenues for the Comparative Study of Political Regimes." In: Politics E) Governance 6.1.

Malesky, Edmund J. (2011). "The Single-Party Dictator's Dilemma: Information in Elections Without Opposition". In: Legislative Studies Quarterly 35.4, pp. 491-530.

Marshall, Monty G., Ted Robert Gurr, and Keith Jaggers (2017). "Polity IV Project: Political regime characteristics and transitions, 1800-2016". In: Available at http : // www . systemicpeace. org/inscrdata. html (accessed on July 6, 2017).

Munck, Gerardo L (2016). "What is democracy? A reconceptualization of the quality of democracy". In: Democratization 23.1, pp. 1-26.

O’Donell, Guillermo (1994). "Delegative democracy". In: Journal of democracy 5.1, pp. 55-69.

Przeworski, Adam (1991). Democracy and the market: Political and economic reforms in Eastern Europe and Latin America. Cambridge University Press.

- (2009). "Force, Wealth, and Elections". In: New York, New York University.

Rezvani, David A (2012). "Dead autonomy, a thousand cuts or partial independence? The autonomous status of Hong Kong". In: Journal of Contemporary Asia 42.1, pp. 93-122.

Schedler, Andreas (2002). "The Nested Game of Democratization by Elections". In: International Political Science Review 23.1, pp. 103-123.

Schumpeter, Joseph A (1976 [1942]). Capitalism, socialism and democracy. Routledge: London and New York.

Teorell, Jan, Michael Coppedge, Staffan Lindberg, and Svend-Erik Skaaning (2019). "Measuring polyarchy across the globe, 1900-2017". In: Studies in Comparative International Development 54.1, pp. 71-95.

Treier, Shawn and Simon Jackman (2008). "Democracy as a latent variable". In: American Journal of Political Science 52.1, pp. 201-217.

Weingast, Barry R. (1997). "The Political Foundations of Democracy and the Rule of Law". In: American Political Science Review 91.2, pp. 245-263. 


\section{OnLine ApPendix to \\ "Visualizing Authority Patterns \\ OVER SPACE AND Time"}

\section{A The cube of democracy patterns for 1950 and 1990}

Color coding by Regimes of the World Index, Lührmann, Tannenberg, and Lindberg, 2018
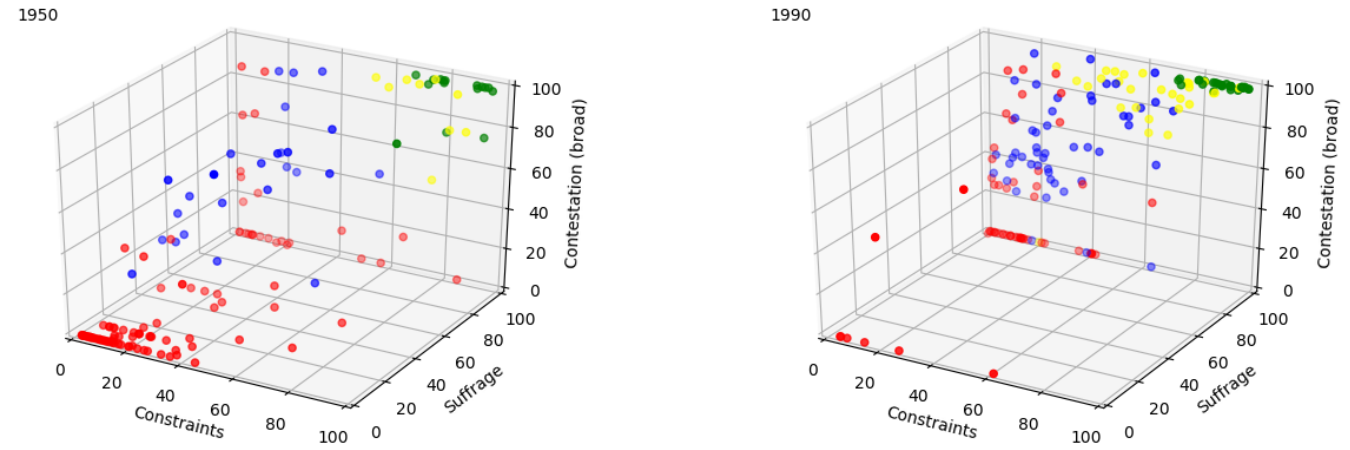

Figure 12: Narrow participation model
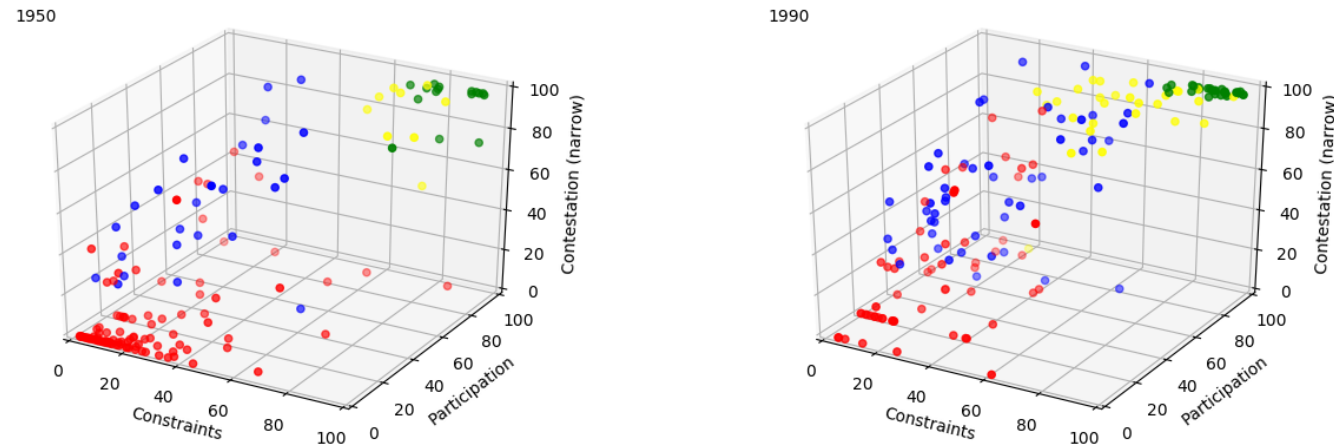

Figure 13: Broad participation model 


\section{B Components of the dimensions}

\begin{tabular}{|c|c|c|}
\hline \multicolumn{3}{|c|}{ Narrow Participation Model } \\
\hline constraints on the executive & participation & contestation \\
\hline - v2x_jucon & - v2x_suffr & - v2elembaut \\
\hline - v2xlg_legcon & & - v2elembcap \\
\hline & & - v2elintim \\
\hline & & - v2x_elecoff \\
\hline & & - v2elrgstry \\
\hline & & - v2elvotbuy \\
\hline & & - v2elirreg. \\
\hline \multicolumn{3}{|c|}{ BroAd PARTiCIPATION MODEL: } \\
\hline constraints on the executive & participation & contestation \\
\hline - v2x_jucon & - v2x_suffr & - v2elembaut \\
\hline - v2xlg_legcon & - v2elrgstry & - v2elembcap \\
\hline & - v2elvotbuy & - v2elintim \\
\hline & - v2elirreg. & - v2x_elecoff \\
\hline
\end{tabular}

Table 7: Overview of V-Dem Indicators that contributed to the dimensions in both models 


\section{Factor Analysis}

The participation and contestation dimensions of the cube of democracy patterns were in part obtained using factor analysis. Below you find detailed information on each of these analyses.

Each of the indicators included in the factor analysis was re-scaled between 0-1 using a cdf-transformation and repeated over election periods (as detailed in Section 2.3). The predicted dimensions from the factor analysis are again re-scaled between 0-1 using a cdf-transformation.

Table 8 displays the three latent variables (printed in bold letters) we coded using factor analysis: a joint voter \& candidate contestation variables for the contestation dimension of the narrow participation model as well as voter contestation and a candidate contestation variable for the broad participation model. In the broad participation model any indicators affecting contestation on the voter's level is included in the participation dimension. Therefore, voter contestation is included in the participation dimension of said model. Table 8 also displays the low-level indicators used to derive the latent variables. In the following we provide the factor analysis results for each of the three latent variables.

\begin{tabular}{|c|c|c|c|}
\hline model & dimension & components & origin \\
\hline \multirow[t]{3}{*}{ narrow participation } & participation & suffrage & v2x_suffr \\
\hline & contestation & voter \& candidate contestation & $\begin{array}{l}\text { factor analysis of } \\
\text { v2elembaut, v2elembcap, } \\
\text { v2elintim, v2elrgstry, } \\
\text { v2elvotbuy, v2elirreg }\end{array}$ \\
\hline & & Elected Officials Index & v2x_elecoff \\
\hline \multirow{4}{*}{ broad participation } & participation & suffrage & ve $\overline{2}$ x_suffr \\
\hline & & voter contestation & $\begin{array}{l}\text { factor analysis of } \\
\text { v2elrgstry, v2elvotbuy, } \\
\text { v2elirreg }\end{array}$ \\
\hline & contestation & candidate contestation & $\begin{array}{l}\text { factor analysis of } \\
\text { v2elembaut, v2elembcap, } \\
\text { v2elintim }\end{array}$ \\
\hline & & Elected Officials Index & v2x_elecoff \\
\hline
\end{tabular}

Table 8: Overview of latent variables (in bold), their corresponding input and the dimensions as well as models they are used in

Tables 9 to 14 display the factor analysis results as well as the factor loadings and unique variances for each of the three latent contestation measures. 


\section{Voter \& candidate contestation}

\begin{tabular}{lrrr} 
Factor & Eigenvalue & Proportion & Cumulative \\
\hline 1 & 4,60 & 0,97 & 0,97 \\
2 & 0,27 & 0,06 & 1,03 \\
3 & 0,06 & 0,01 & 1,04 \\
4 & $-0,03$ & $-0,01$ & 1,04 \\
5 & $-0,06$ & $-0,01$ & 1,02 \\
6 & $-0,12$ & $-0,02$ & 1,00 \\
\hline \hline
\end{tabular}

Table 9: Factor analysis results for voter \& candidate contestation

\begin{tabular}{lrr} 
Variable & Factor 1 & Uniqueness \\
\hline v2elembaut & 0,82 & 0,32 \\
v2elembcap & 0,82 & 0,33 \\
v2elintim & 0,89 & 0,20 \\
v2elrgstry & 0,90 & 0,18 \\
v2elvotbuy & 0,87 & 0,25 \\
v2elirreg & 0,94 & 0,12 \\
\hline \hline
\end{tabular}

Table 10: Factor loadings and unique variances, voter \& candidate contestation

Kaiser-Meyer-Olkin measure $($ overall $)=0.87$

\section{Voter contestation}

\begin{tabular}{lrrr} 
Factor & Eigenvalue & Proportion & Cumulative \\
\hline 1 & 2,48 & 1,05 & 1,05 \\
2 & $-0,03$ & $-0,01$ & 1,03 \\
3 & $-0,08$ & $-0,03$ & 1,00 \\
\hline \hline
\end{tabular}

Table 11: Factor analysis results for voter contestation

\begin{tabular}{lrr} 
Variable & Factor 1 & Uniqueness \\
\hline v2elrgstry & 0,87 & 0,24 \\
v2elvotbuy & 0,91 & 0,18 \\
v2elirreg & 0,95 & 0,10 \\
\hline \hline
\end{tabular}

Table 12: Factor loadings and unique variances, voter contestation

Kaiser-Meyer-Olkin measure $($ overall $)=0.74$

\section{Candidate contestation}

\begin{tabular}{lrrr} 
Factor & Eigenvalue & Proportion & Cumulative \\
\hline 1 & 2,13 & 1,10 & 1,10 \\
2 & $-0,06$ & $-0,03$ & 1,07 \\
3 & $-0,13$ & $-0,07$ & 1,00 \\
\hline \hline
\end{tabular}

Table 13: Factor analysis results for candidate contestation

\begin{tabular}{lrr} 
Variable & Factor 1 & Uniqueness \\
\hline v2elembaut & 0,89 & 0,20 \\
v2elembcap & 0,83 & 0,31 \\
v2elintim & 0,80 & 0,36 \\
\hline \hline
\end{tabular}

Table 14: Factor loadings and unique variances, candidate contestation

Kaiser-Meyer-Olkin measure $($ overall $)=0.73$ 


\section{Number of countries in sample over time}

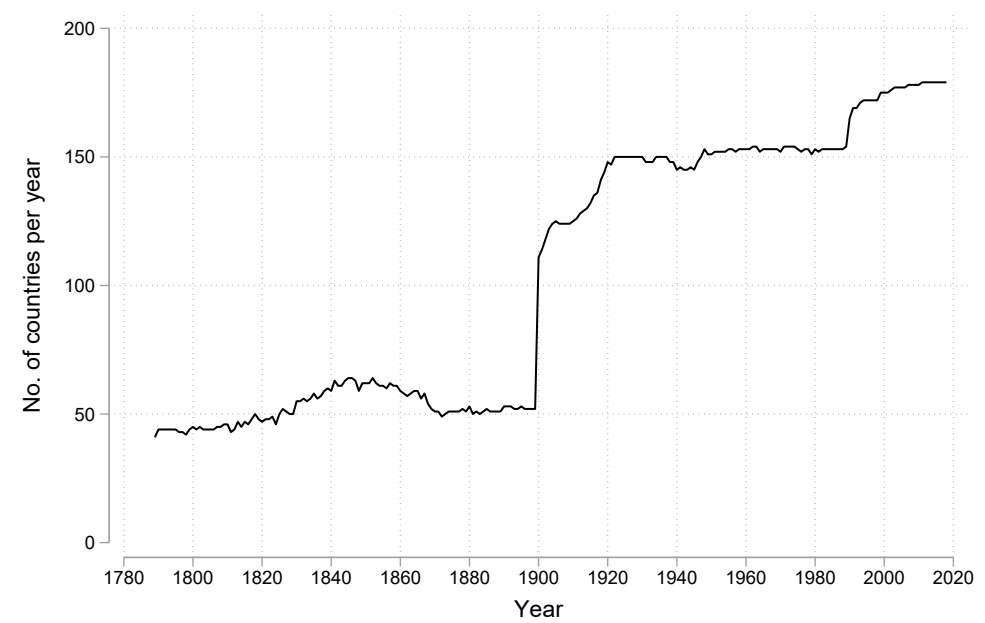

Figure 14: Number of countries in sample over time

\section{E Missing values in election specific indicators}

Several V-Dem indicators, such as election vote buying and election monitoring board autonomy, are election-specific. These are coded by country-experts only in years when there are elections. In order to include such election-specific in the construction of our democracy dimensions, we thus follow V-Dem's practice, as described by Teorell et al. (2019), and "interpolate between elections until there is an "electoral interruption," defined as either (i) the dissolution, shutdown, replacement, or in any sense termination of the elected body (such as after coups or violent takeovers of the government) or (ii) an elected body which, while still intact or in place, is no longer appointed through (direct) elections (as after an autogolpe)" (p. 80). Whenever there is an electoral interruption, or, more generally, elections are not on course (including in non-electoral regimes such as current Saudi Arabia), the election-specific indicators are given the minimum value (0 for normalized variables) . 


\section{F Countries and respective time series included in anal- ysis}

Table 15: Countries and respective time series included in analysis. $T_{i}$ refers to the total number of years each country $i$ is included in the data.

\begin{tabular}{|c|c|c|c|}
\hline country $i$ & first year coded & last year coded & $T_{i}$ \\
\hline Afghanistan & 1900 & 2018 & 119 \\
\hline Albania & 1912 & 2018 & 107 \\
\hline Algeria & 1900 & 2018 & 119 \\
\hline Angola & 1900 & 2018 & 119 \\
\hline Argentina & 1789 & 2018 & 188 \\
\hline Armenia & 1990 & 2018 & 29 \\
\hline Australia & 1789 & 2018 & 226 \\
\hline Austria & 1789 & 2018 & 208 \\
\hline Azerbaijan & 1990 & 2018 & 29 \\
\hline Baden & 1789 & 1870 & 82 \\
\hline Bahrain & 2002 & 2018 & 17 \\
\hline Bangladesh & 1971 & 2018 & 48 \\
\hline Barbados & 1900 & 2018 & 119 \\
\hline Bavaria & 1818 & 1870 & 53 \\
\hline Belarus & 1990 & 2018 & 29 \\
\hline Belgium & 1900 & 2018 & 119 \\
\hline Benin & 1900 & 2018 & 119 \\
\hline Bhutan & 1900 & 2018 & 119 \\
\hline Bolivia & 1825 & 2018 & 194 \\
\hline Bosnia and Herzegovina & 1992 & 2018 & 27 \\
\hline Botswana & 1900 & 2018 & 119 \\
\hline Brazil & 1789 & 2018 & 228 \\
\hline Brunswick & 1789 & 1867 & 74 \\
\hline Bulgaria & 1878 & 2018 & 141 \\
\hline Burkina Faso & 1919 & 2018 & 75 \\
\hline Burma/Myanmar & 1789 & 2018 & 230 \\
\hline Burundi & 1916 & 2018 & 102 \\
\hline Cambodia & 1900 & 2018 & 118 \\
\hline Cameroon & 1961 & 2018 & 58 \\
\hline Canada & 1841 & 2018 & 177 \\
\hline Cape Verde & 1900 & 2018 & 119 \\
\hline Central African Republic & 1920 & 2018 & 97 \\
\hline Chad & 1920 & 2018 & 99 \\
\hline Chile & 1789 & 2018 & 210 \\
\hline China & 1789 & 2018 & 230 \\
\hline Colombia & 1789 & 2018 & 229 \\
\hline Comoros & 1900 & 2018 & 87 \\
\hline Costa Rica & 1844 & 2018 & 175 \\
\hline Croatia & 1941 & 2018 & 32 \\
\hline Cuba & 1789 & 2018 & 227 \\
\hline \multicolumn{4}{|c|}{ Continued on next page } \\
\hline
\end{tabular}


Table 15 - continued from previous page

\begin{tabular}{|c|c|c|c|}
\hline country $i$ & first year coded & last year coded & $T_{i}$ \\
\hline Cyprus & 1900 & 2018 & 119 \\
\hline Czech Republic & 1918 & 2018 & 100 \\
\hline Democratic Republic of the Congo & 1900 & 2018 & 119 \\
\hline Denmark & 1789 & 2018 & 228 \\
\hline Djibouti & 1900 & 2018 & 119 \\
\hline Dominican Republic & 1844 & 2018 & 174 \\
\hline Ecuador & 1830 & 2018 & 186 \\
\hline Egypt & 1789 & 2018 & 194 \\
\hline El Salvador & 1838 & 2018 & 130 \\
\hline Equatorial Guinea & 1900 & 2018 & 119 \\
\hline Eritrea & 1900 & 2018 & 119 \\
\hline Estonia & 1918 & 2018 & 49 \\
\hline Ethiopia & 1789 & 2018 & 230 \\
\hline Fiji & 1900 & 2018 & 119 \\
\hline Finland & 1863 & 2018 & 156 \\
\hline France & 1791 & 2018 & 228 \\
\hline Gabon & 1910 & 2018 & 108 \\
\hline Georgia & 1990 & 2018 & 28 \\
\hline German Democratic Republic & 1950 & 1990 & 41 \\
\hline Germany & 1789 & 2018 & 226 \\
\hline Ghana & 1902 & 2018 & 117 \\
\hline Greece & 1822 & 2018 & 195 \\
\hline Guatemala & 1789 & 2018 & 224 \\
\hline Guinea & 1900 & 2018 & 119 \\
\hline Guinea-Bissau & 1900 & 2018 & 119 \\
\hline Guyana & 1900 & 2018 & 119 \\
\hline Haiti & 1789 & 2018 & 227 \\
\hline Hanover & 1789 & 1865 & 75 \\
\hline Hesse-Darmstadt & 1790 & 1871 & 82 \\
\hline Honduras & 1838 & 2018 & 181 \\
\hline Hong Kong & 1900 & 2018 & 119 \\
\hline Hungary & 1789 & 2018 & 222 \\
\hline Iceland & 1900 & 2018 & 119 \\
\hline India & 1789 & 2018 & 230 \\
\hline Indonesia & 1800 & 2018 & 219 \\
\hline Iran & 1900 & 2018 & 119 \\
\hline Iraq & 1920 & 2018 & 99 \\
\hline Ireland & 1919 & 2018 & 100 \\
\hline Israel & 1948 & 2018 & 71 \\
\hline Italy & 1862 & 2018 & 157 \\
\hline Ivory Coast & 1900 & 2018 & 119 \\
\hline Jamaica & 1901 & 2018 & 118 \\
\hline Japan & 1875 & 2018 & 144 \\
\hline Jordan & 1922 & 2018 & 97 \\
\hline Kazakhstan & 1991 & 2018 & 28 \\
\hline Kenya & 1900 & 2018 & 119 \\
\hline
\end{tabular}


Table 15 - continued from previous page

\begin{tabular}{|c|c|c|c|}
\hline country $i$ & first year coded & last year coded & $T_{i}$ \\
\hline Kosovo & 1999 & 2018 & 20 \\
\hline Kuwait & 1900 & 2018 & 119 \\
\hline Kyrgyzstan & 1990 & 2018 & 29 \\
\hline Laos & 1900 & 2018 & 119 \\
\hline Latvia & 1920 & 2018 & 49 \\
\hline Lebanon & 1919 & 2018 & 100 \\
\hline Lesotho & 1900 & 2018 & 119 \\
\hline Liberia & 1839 & 2018 & 179 \\
\hline Libya & 1934 & 2018 & 76 \\
\hline Lithuania & 1918 & 2018 & 51 \\
\hline Luxembourg & 1915 & 2018 & 104 \\
\hline Macedonia & 1991 & 2018 & 28 \\
\hline Madagascar & 1817 & 2018 & 202 \\
\hline Malawi & 1900 & 2018 & 119 \\
\hline Malaysia & 1900 & 2018 & 113 \\
\hline Maldives & 1900 & 2018 & 118 \\
\hline Mali & 1900 & 2018 & 119 \\
\hline Malta & 1900 & 2018 & 118 \\
\hline Mauritania & 1904 & 2018 & 115 \\
\hline Mauritius & 1900 & 2018 & 119 \\
\hline Mecklenburg Schwerin & 1789 & 1867 & 78 \\
\hline Mexico & 1789 & 2018 & 229 \\
\hline Modena & 1797 & 1797 & 1 \\
\hline Moldova & 1990 & 2018 & 29 \\
\hline Mongolia & 1911 & 2018 & 108 \\
\hline Montenegro & 1789 & 2018 & 148 \\
\hline Morocco & 1912 & 2018 & 107 \\
\hline Mozambique & 1900 & 2018 & 98 \\
\hline Namibia & 1900 & 2018 & 118 \\
\hline Nepal & 1900 & 2018 & 119 \\
\hline Netherlands & 1789 & 2018 & 225 \\
\hline New Zealand & 1841 & 2018 & 142 \\
\hline Nicaragua & 1901 & 2018 & 118 \\
\hline Niger & 1922 & 2018 & 97 \\
\hline Nigeria & 1914 & 2018 & 104 \\
\hline North Korea & 1945 & 2018 & 74 \\
\hline Norway & 1807 & 2018 & 210 \\
\hline Oldenburg & 1813 & 1813 & 1 \\
\hline Oman & 1900 & 2018 & 119 \\
\hline Pakistan & 1947 & 2018 & 72 \\
\hline Palestine/British Mandate & 1918 & 1948 & 31 \\
\hline Palestine/Gaza & 1948 & 2018 & 31 \\
\hline Palestine/West Bank & 1948 & 2018 & 18 \\
\hline Panama & 1903 & 2018 & 116 \\
\hline Papal States & 1790 & 1861 & 67 \\
\hline Papua New Guinea & 1900 & 2018 & 116 \\
\hline
\end{tabular}


Table 15 - continued from previous page

\begin{tabular}{|c|c|c|c|}
\hline country $i$ & first year coded & last year coded & $T_{i}$ \\
\hline Paraguay & 1811 & 2018 & 206 \\
\hline Parma & 1789 & 1859 & 59 \\
\hline Peru & 1821 & 2018 & 193 \\
\hline Philippines & 1900 & 2018 & 119 \\
\hline Piedmont-Sardinia & 1789 & 1860 & 69 \\
\hline Poland & 1789 & 2018 & 161 \\
\hline Portugal & 1834 & 2018 & 185 \\
\hline Qatar & 1900 & 2018 & 119 \\
\hline Republic of Vietnam & 1902 & 1975 & 74 \\
\hline Republic of the Congo & 1903 & 2018 & 116 \\
\hline Romania & 1789 & 2018 & 184 \\
\hline Russia & 1789 & 2018 & 230 \\
\hline Rwanda & 1916 & 2018 & 102 \\
\hline Sao Tome and Principe & 1900 & 2018 & 119 \\
\hline Saudi Arabia & 1789 & 2018 & 227 \\
\hline Saxe-Weimar-Eisenach & 1815 & 1867 & 38 \\
\hline Saxony & 1789 & 1867 & 79 \\
\hline Senegal & 1904 & 2018 & 115 \\
\hline Serbia & 1835 & 2018 & 176 \\
\hline Seychelles & 1903 & 2018 & 116 \\
\hline Sierra Leone & 1900 & 2018 & 119 \\
\hline Singapore & 1900 & 2018 & 119 \\
\hline Slovakia & 1993 & 2018 & 26 \\
\hline Slovenia & 1989 & 2018 & 30 \\
\hline Solomon Islands & 1900 & 2018 & 119 \\
\hline Somalia & 1900 & 2018 & 119 \\
\hline Somaliland & 1900 & 2018 & 87 \\
\hline South Africa & 1900 & 2018 & 119 \\
\hline South Korea & 1789 & 2018 & 230 \\
\hline South Sudan & 2011 & 2018 & 8 \\
\hline South Yemen & 1900 & 1990 & 91 \\
\hline Spain & 1789 & 2018 & 229 \\
\hline Sri Lanka & 1900 & 2018 & 118 \\
\hline Sudan & 1900 & 2018 & 119 \\
\hline Suriname & 1900 & 2018 & 119 \\
\hline Swaziland & 1900 & 2018 & 119 \\
\hline Sweden & 1789 & 2018 & 229 \\
\hline Switzerland & 1798 & 2018 & 221 \\
\hline Syria & 1918 & 2018 & 99 \\
\hline Taiwan & 1900 & 2018 & 119 \\
\hline Tajikistan & 1990 & 2018 & 29 \\
\hline Tanzania & 1915 & 2018 & 104 \\
\hline Thailand & 1900 & 2018 & 119 \\
\hline The Gambia & 1900 & 2018 & 119 \\
\hline Timor-Leste & 1999 & 2018 & 20 \\
\hline Togo & 1916 & 2018 & 103 \\
\hline
\end{tabular}


Table 15 - continued from previous page

\begin{tabular}{|c|c|c|c|}
\hline country $i$ & first year coded & last year coded & $T_{i}$ \\
\hline Trinidad and Tobago & 1900 & 2018 & 119 \\
\hline Tunisia & 1789 & 2018 & 230 \\
\hline Turkey & 1789 & 2018 & 230 \\
\hline Turkmenistan & 1991 & 2018 & 28 \\
\hline Tuscany & 1800 & 1861 & 16 \\
\hline Two Sicilies & 1808 & 1821 & 10 \\
\hline Uganda & 1900 & 2018 & 119 \\
\hline Ukraine & 1990 & 2018 & 29 \\
\hline United Arab Emirates & 1971 & 2018 & 48 \\
\hline United Kingdom & 1789 & 2018 & 149 \\
\hline United States of America & 1790 & 2018 & 229 \\
\hline Uruguay & 1825 & 2018 & 194 \\
\hline Uzbekistan & 1789 & 2018 & 160 \\
\hline Vanuatu & 1900 & 2018 & 118 \\
\hline Venezuela & 1789 & 2018 & 220 \\
\hline Vietnam & 1945 & 2018 & 74 \\
\hline Würtemberg & 1789 & 1871 & 82 \\
\hline Yemen & 1789 & 2018 & 163 \\
\hline Zambia & 1911 & 2018 & 108 \\
\hline Zanzibar & 1905 & 2018 & 107 \\
\hline Zimbabwe & 1902 & 2018 & 117 \\
\hline
\end{tabular}




\section{G Case studies for the broad participation model}

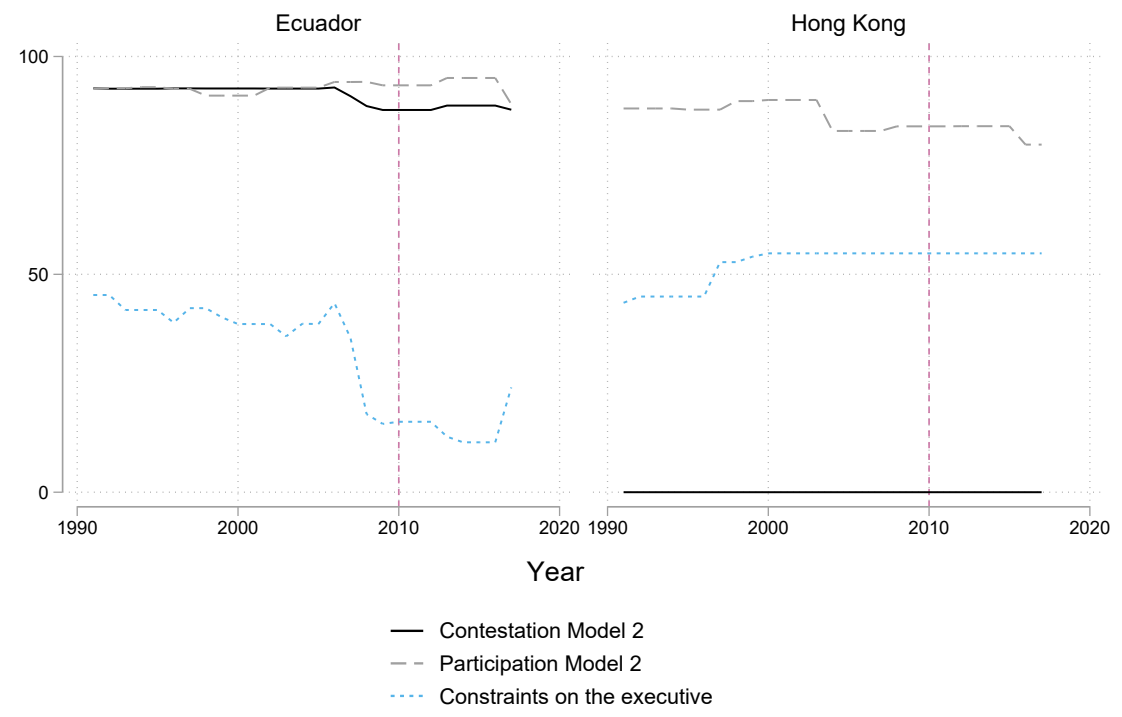

Figure 15: Broad participation model: contestation, participation and constraints for Ecuador and Hong Kong

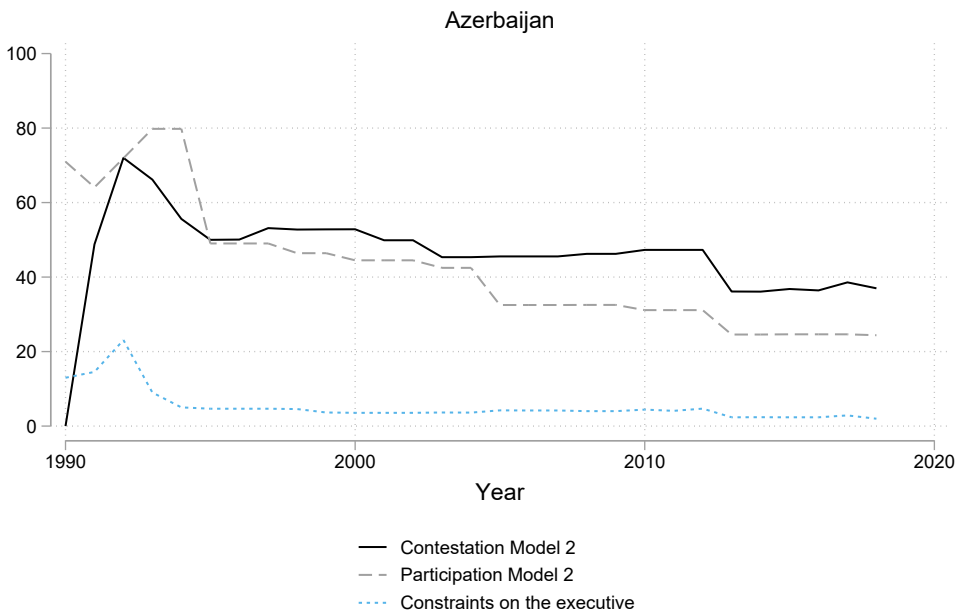

Figure 16: Broad participation model: contestation, participation and constraints for Azerbaijan 


\section{H Broad participation model:}

\section{Average global and regional trends}

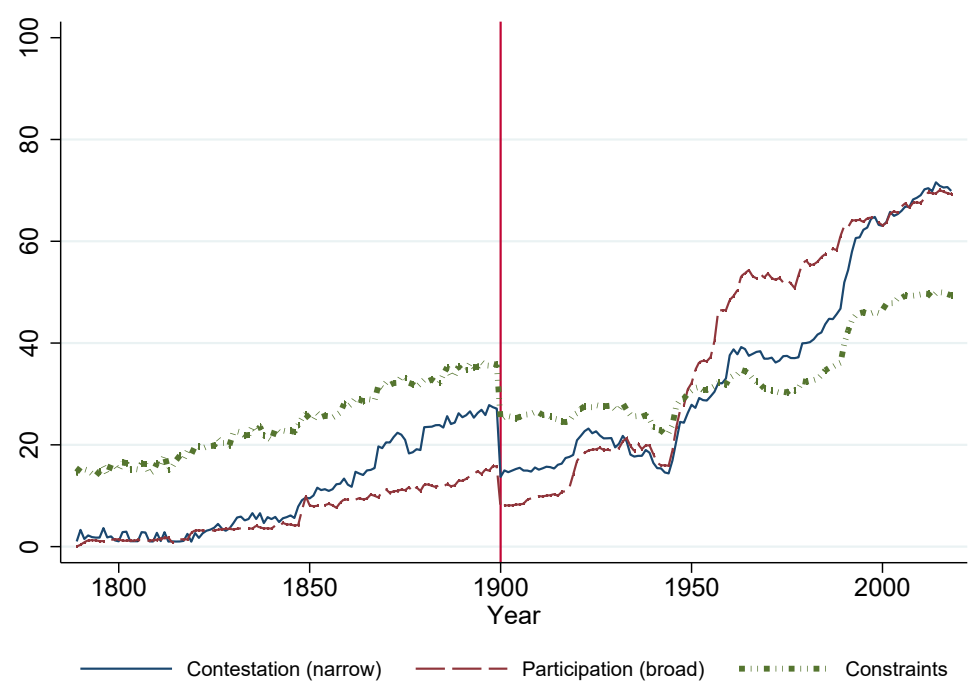

Figure 17: Global average participation (broad), contestation (candidates/parties), and constraints, 1789-2018. The vertical line marks the major expansion of the sample from year 1899 to year 1900, notably adding a number of African and Asian colonies. 


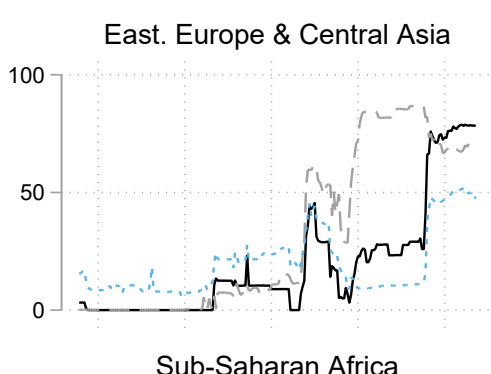

Latin America \& Caribbean

Middle East \& North Africa
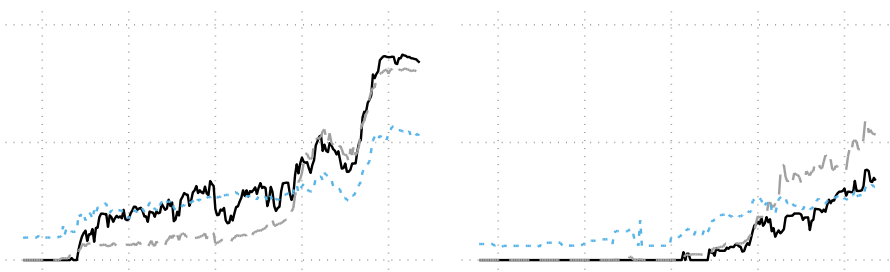

West. Europe \& North America
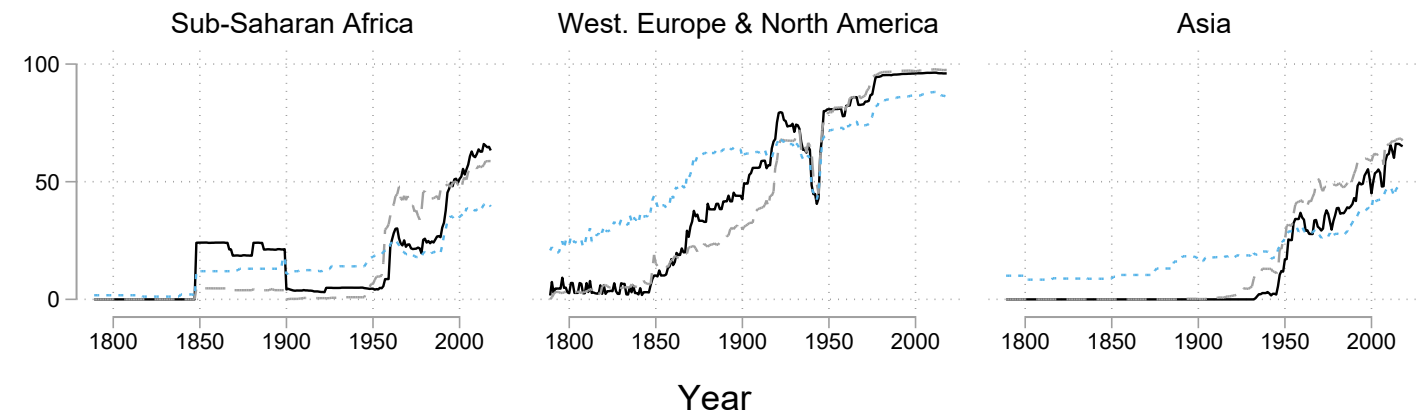

- Contestation (narrow)

- - Broad participation

.... Constraints on the executive

Figure 18: Broad participation model: average participation, contestation and constraints on the executive across World regions, 1789 - 2018 